\title{
Through Rainy Days: Advancing Education and Health amidst an Unfavorable Local Economy
}

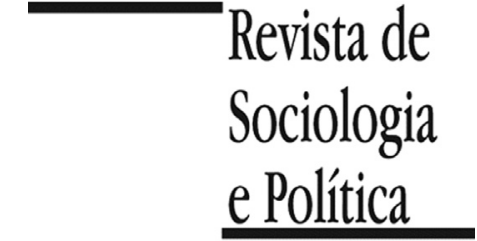

DOI $10.1590 / 1678987318266801$

\begin{abstract}
Ana Paula KarruziD
ABSTRACT Introduction: While life standards have substantially ameliorated in Brazil, the last few years witnessed a slow-growing economy, raising concerns on whether educational and public health improvements will endure. Questions are posed regarding how governments countrywide may shelter against economic turbulence and keep improving social conditions through rainy days. In particular, what public policy can do to sustain or even increase human development (HD) in the absence of economic growth (EG)? Materials and Methods: This study explores the sociodemographic and budgetary traits of Brazilian municipalities that experienced less-than-expected growth in the Municipal Human Development Index (MHDI)'s income dimension, nonetheless advanced more than expected on schooling and longevity. Municipalities whose mean per capita income advanced less than foreseen were grouped according to growth in MHDI's social dimensions. Chances of falling into a given group were estimated through a multinomial logit model. Results: The analysis suggests that, in a stalled or slow economy, the probability of social improvement is sensitive to families' income level, educational achievement in households with children, local budget composition and apportionment, age and size of population, and already existing HD levels. Discussion: I argue that non-income influences - namely, public policy from central and local governments - can have substantive effects on HD, containing losses or even promoting HD advancements amidst an unfavorable economy. Such assertion builds upon works from Development Studies, adapting them from the cross-country perspective to the cross-municipality level. Additionally, research on decentralization and fiscal federalism provide grounds for adjusting the theoretical model. A more balanced countrywide distribution of family and government resources foreshadows lesser vulnerability through rainy days.
\end{abstract}

KEYWORDS: human development, economic growth, social spending, municipality, Brazil.

Received in February 6, 2017. Accepted in December 24, 2018.

\section{Introduction ${ }^{1}$}

\footnotetext{
${ }^{1}$ I thank the anonymous reviewers of Revista de Sociologia e Política for their comments on this article. I also thank Márcia Miranda Soares for comments on preliminary findings. All errors are mine. This study was financed in part by the Coordenação de Aperfeiçoamento de Pessoal de Nível Superior - Brasil (CAPES) - Finance Code 001.
}

$\mathrm{S}$ ince the late twentieth century, improvements in social conditions have left behind the status of a by-product of economic growth (EG), to become reputed by the development theory as a critical input to income expansion (Sen 1999; Ranis, Stewart \& Ramirez 2000; Evans \& Heller 2015). Concomitantly, the broad notion of human development (HD), "defined as improving the choices of individuals to enable them to lead longer, healthier and fuller lives" (Suri et al., 2011, 506), gained notoriety as a depiction of what development should aim. The two-way causation between EG and HD has since been extensively noted (Ranis, Stewart \& Ramirez 2000; Ranis \& Stewart 2001; Baldacci et al., 2008; Suri et al., 2011).

However, what is of HD in a scenario of growth contraction or even downturn? HD can improve in the absence of income raises, and the latter may not entail the former. Simply put, "there is no automatic link between income and human development" (UNDP 2015, p.56). As a first reason for that, the sheer amount of resources controlled or produced by a community tells nothing about how they are distributed among members. Second, mere acquiring of income is no guarantee that it will be allocated according to priorities and long-term decisions that build HD. Third, the outcome of such decisions is determined, but only partially, by the amount spent - quantity and quality are distinct concepts. Finally, on top of individual choices, societies are impacted by the action of 
governments. Here, too, the three first points apply: public policies concur to redistribute capital, to establish and pursue specific priorities, and they may do so to a greater or lesser degree of efficiency and quality.

In particular, what can public policy do to sustain or even increase HD in the absence of EG? This work sets out to explore possible intervening factors, especially those linked to local government spending, that could help understand contexts in which social indicators advance despite a stalled economy. This is a notably relevant topic in current Brazil. While the country has substantially improved its living standards, the last few years witnessed an economic slowdown, raising concerns on whether educational and public health improvements will endure the harsh budgetary cuts since 2014 and the 2015-6 recession. Most importantly, questions are posed regarding how governments countrywide may shelter against economic turbulence and keep improving social conditions through rainy days.

I argue that non-income influences - namely, public policy from central and local governments - can have substantive effects on HD, containing losses or even promoting HD advancements amidst an unfavourable economy. Such assertion builds upon works from Development Studies (e.g., Baldacci et al., 2008; Suri et al., 2011), but extrapolates and adapts them from the cross-country perspective to the cross-municipality level. Additionally, research on decentralisation of public policy responsibilities and fiscal federalism (e.g., Arretche 2012; Soares \& Melo 2016; Bueno 2017) provides the grounds for adjusting the models of HD to the context of Brazilian municipalities.

Specifically, this study searches for shared sociodemographic and budgetary traits of over 1,800 Brazilian localities whose Municipal Human Development Index (MHDI)'s income dimension advanced less than anticipated, however at the same time experienced more than expected growth in schooling and longevity over the 2000-2010 period. Beyond the practical relevance of the object, the present study brings new evidence on non-income factors influencing $\mathrm{HD}$ at the municipality level and evaluates the impact of local budget sources and applications on HD.

The remainder pages are organised as follows. Section II reports the theoretical understanding of the relationship between HD dimensions and synthesises empirical studies on HD convergence - which are the basis for calculating expected MHDI growth rates. Section III covers public policies as forces that shape HD, with a focus on the decentralisation of education and health services provision, state capacity, sources and spending autonomy in local budgets, and lays down hypotheses. Section IV explains the methodology. Regression estimates are presented in Section V; results are discussed in the concluding section.

\section{Multiple influences over HD}

\section{II.1. A complex system of interwoven connections}

As it would be expected of a rather ample concept, HD is affected by and affects a long list of socioeconomic factors. The two-way relationship between economic progress and HD was charted by Ranis, Stewart \& Ramirez (2000), Ranis \& Stewart (2001), and Suri et al. (2011). Given past EG, families, governments and the civil society make allocative decisions on consumption (e.g., in better nutrition) and investment (e.g., saving for college) that are, to a greater or lesser degree, HD-enhancing. Naturally, EG is itself modified by family, government and civil society actions. The emerging picture is that of a deeply interconnected system of direct, indirect and feedback links shaping HD. With this 
complexity level, no automatic causation between income rise and the latitude of human choices should be taken for granted.

For the sake of parsimony, take the two sets of players that most directly affect HD. Income levels import for a country's education and health indicators (e.g., Baldacci et al., 2008; Suri et al., 2011). However, families' resources are not well depicted by country, state or local averages; income inequality has to be accounted for, as well as the extent to which poverty has been alleviated. In spite of a higher propensity to consume HD-related items, low-income families are doomed to a limited acquisition of such items. Notwithstanding, after controlling for income inequality and other quality of life aspects, income level tends to lose statistical significance as a predictor of morbidity and mortality (Kenny 2005). Moreover, in the decision dynamics within families, gender and schooling of household heads - those in charge of finances, often the family member who accrues the largest income share - make a difference. Womenheaded households tend to spend more in HD-enhancing goods and services, such as groceries, water and education (Ranis, Stewart \& Ramirez 2000); women's education positively correlates with the probability of controlling domestic allocative choices and is itself a driving force for ameliorating nutrition and child survival rates (Schultz 2002).

Beyond improved allocation of available resources, the very nature of these resources is crucial. Departing from an income-centric perspective, Ranis \& Stewart $(2001,6)$ defend that social capital, "the available horizontal links among actors", may amplify the benefits from EG - or mute the consequences of a downtrend. Also, any reasonable account to the plunge in mortality rates over the 1900s would have to include knowledge, science and technology, argue Cutler, Deaton and Lleras-Muney (2006). Understanding of available technologies may cheapen HD inputs (e.g., preventive medical care, adequate nutrition and quality education), and the latter may reinforce each other through symbiotic connections. Consider, for instance, how vaccines and some inexpensive interventions (e.g., professionally training midwives) dramatically reduce health care costs (Ranis \& Stewart 2001; Kenny 2005; 2009), and the potential boost in schooling, nutrition and self-esteem brought by conditional cash transfer programs such as Oportunidades (formerly known as Progresa) in Mexico and Programa Bolsa Família, in Brazil. Besides, there is evidence of a robust and bilateral association between education and health, in part supported by the fact that formally educated people are more likely to assimilate medical and sanitation technologies (Kenny 2005; 2009; for links between education and health, see Weare 2002; Oliveira 2005; Cutler \& Lleras-Muney 2006; Feinstein et al., 2006; and Brunello et al., 2011).

\section{II.2. Convergence in HD}

Factors touched upon in previous paragraphs tell a story about a multicausal phenomenon, whose determinants are of varied natures and find themselves intertwined by complex bonds. Put this way it is not surprising that income growth is only one facet of HD and that it may not guarantee the latter. However, there is more to it. Initial levels, of both income and other quality of life indicators, also dictate the speed of HD growth. The marginal effect of income on HD tends to decline (Kenny 2005), and an overall pattern of slow but consistent convergence has been found both cross-country and among Brazilian municipalities (Karruz \& Vale 2015). Bounded indicators certainly play a role in reducing disparities - after all, no place can go above 100 per cent literacy rate, and present life expectation will not top the vicinity of 100 years (Kenny 2005; Noorbakhsh 2006). 
Most of the literature on convergence deals with trajectories of per capita income among countries (e.g., Barseghyan \& Dicecio 2011; Dhongde \& Miao 2013), states (e.g., Galeano 2014) and municipalities (e.g., Coelho \& Figueiredo 2007; Ferreira \& Cruz 2008; Ribeiro \& Almeida 2012). A smaller group of scholars has applied the notion of convergence to report HD trends, and studies of this nature typically analyse the country level (Kenny 2005; Noorbakhsh 2006; Kónya \& Guisan 2008; Mayer-Foulkes 2010; Kónya 2011; Jordá \& Sarabia 2015a; 2015b).

Convergence studies share the concern about spatial inequalities and the speed at which less advanced regions seem to catch up towards the highest development levels experienced by other regions. Most of these studies cite the seminal works of Robert Solow (1956) and Trevor Swan (1956). These authors proposed neo-classical growth models predicting that, given perfectly free markets, capital investments would travel the world after the highest return rates. With capital's diminishing returns, best investment opportunities would concentrate in the least developed areas, where the stock of capital of capital is lower. According to this view, regional disparities would disappear, and income convergence would be expected. An alternative perspective foresees an entirely different outcome. As per the cumulative circular causation principle, capital and skilled labour would cluster in certain areas due to economies of scale and agglomeration, possibly generating a pattern of lingering inequality. This view has been associated with the work of Myrdal (1968), Dixon and Thirlwall (1975) and Kaldor (1978), explain Marques and Fochezatto (2012). Note that income convergence accounts provided above regard markets or territorial units much more so than a convergence of families' income.

As an extrapolation from the income studies, HD convergence claims that diminishing marginal returns apply to non-economic dimensions as well. Here, the insight is that basic education and health services (e.g., primary education, immunisation) tend to cost considerably less than their advanced counterparts (e.g., higher education, open-heart surgery). With the same dollar amount, a larger quality of life return would accrue in less developed areas, which are still struggling to meet basic and less expensive demands. HD convergence could then take place (Kenny 2005; Noorbakhsh 2006).

Empirical research has found slow HD convergence between countries (Noorbakhsh 2006; Kónya \& Guisan 2008; Jordá \& Sarabia 2015a). Considering each HD dimension separately, Mayer-Foulkes (2010) observed a series of superposed transitions marked by initial divergence followed by periods of convergence, with urbanisation playing a central role in promoting the latter. Social policies are arguably more straightforward to implement in urban than rural areas (Kenny 2005), and urban dwellers are more likely to send their children to school, due to the typically facilitated access and lower private costs of education (Gupta, Verhoeven \& Tiongson 2002). ${ }^{2}$ Speed of convergence seems to vary across dimensions, and has been more accelerated in schooling (Neumayer 2003; Mayer-Foulkes 2010; Jordá \& Sarabia 2015a). In the Brazilian context, municipality-level HD has been predominantly driven by the schooling dimension (PNUD, IPEA, \& FJP 2013).

Primary education and health care, two key HD-inputs, are policy areas in which Brazilian municipalities take centre stage - and, thus, where service heterogeneity is prone to arise. Next section reviews the literature on the HD implications of public spending in these areas. It also briefly describes the social services provision landscape in Brazil, touching upon topics of regulation and funding. 


\section{Public policy and HD}

III.1. Social spending and HD

${ }^{3}$ Baldacci et al. (2008) review several studies examining the impact of social spending on social indicators. The mixed results presented in the literature could be attributable, at least in part, to limited data availability, measurement problems and faulty model designs, argue these authors.
Governments play a crucial role in fostering HD as both education and health are considered public goods. Total budget and apportionment by function, as well as the distribution of funds between various HD-related programs, are all impinging upon HD results (Ranis \& Stewart 2001).

Based on panel data from 118 developing countries covering years 1975-2000, and after applying several techniques to avoid measurement error and endogeneity, ${ }^{3}$ Baldacci et al. (2008) found that expenditures on education positively associate with accumulations of education capital (primary and secondary gross enrollment rate). Such connection works through both contemporaneous and lagged effects, the latter spanning 10 years. At their turn, positive effects of health spending do not seem cumulative, being detected only a contemporaneous (five-year period) influence over the under-five child mortality rate. Nevertheless, such positive effects of education and health spending are contingent on the quality of governance, portrayed by a combination of corruption and accountability indicators. Poor governance reduces the effects of education spending and nullifies those from health spending, report Baldacci et al. (2008).

Suri et al. (2011) found similar results as they observed panel data ranging from 1960 to 2001 on around 100 developing countries. Their dependent variable was a composite index representing the portion of the variation of three HD indicators (infant mortality, life expectancy, and secondary school enrollment) that is not attributable to a country's income growth rate alone. Per capita public expenditure on education and health both showed a positive effect on HD, whereas income inequality displays a strong adverse effect.

\section{III.2. Decentralisation of education and health services}

Public education and health care are highly decentralised, universal services in Brazil. Public policy decentralisation gained strength in the 1990s, in good part because of the 1988 Constitution, which was built around a political commitment to empower local communities and to expand municipalities' taxation power. Later in that decade, new measures were taken, but now emanating from a different set of motivations. Brazilian municipalities are extremely unequal in population size and composition, economic dynamics, policy needs, managerial capability - and started in very different positions as far as their participation in supplying social policies. To help levelling the field and to overcome local fiscal constraints, the federal government passed constitutional amendments to establish new policy funding designs (Souza 2004), keeping service delivery (policy-making) local, but concentrating policy decision-making at the central level, especially in health care and education (Arretche 2012).

A system of incentives (e.g., new funding availability) and sanctions (e.g., risk of resource loss or impossibility to tap into new sources), combined with strong regulation and service protocols, are arguably the critical design features behind the successful municipalization in primary education and basic public health (Arretche 2002; 2012; Souza 2004). Since Sistema Único de Saúde (SUS, the Unified National Health System) was established in 1988, municipalities have opted to become responsible for health services provision. Many have also adhered to the 1998-launched Fundef (Fundo de Manutenção e Desenvolvimento do Ensino Fundamental e de Valorização do Magistério, loosely translated as Fund for Primary Education Maintenance and Development and Recognition of the Teaching Profession). In 2000, 99.0 per cent of municipali- 
${ }^{4}$ In 2010, 62.6 per cent of all primary education students enrolled in state or municipal schools attended municipal schools (INEP 2017). In 2015, this figure reached 67.3 per cent (INEP 2016). Federal primary education is minimal.

${ }^{5}$ Fundo de Manutenção e Desenvolvimento da Educação Básica e de Valorização dos Profissionais da Educação (Fund for Basic Education Maintenance and Development and Recognition of Education Professionals).

${ }^{6}$ A standardized test focused on assessing education quality of public schools. It is applied to $5^{\text {th }}$ graders, $9^{\text {th }}$ graders and high school seniors by the Instituto Nacional de Estudos e Pesquisas Educacionais Anísio Teixeira, an agency associated with the Ministry of Education. ties had taken over health services supply, whereas municipal schools accounted for 51.4 per cent of primary education enrollment - against 40.7 per cent in 1997 (Souza 2004). ${ }^{4}$

Some key legislation deepened decentralization in the following years. In 2000, Amendment 29 regulated local revenues to be spent in health: a minimum of 7 per cent that year, with yearly increments, reaching 15 per cent by 2004 (Faveret 2003). In 2007, Fundef was replaced by another intergovernmental fund, Fundeb. ${ }^{5}$ Municipalities' contribution to the pooled resources increased from 15 to 20 per cent of revenues, as childcare/pre-school and secondary education were included in the Fundeb per pupil funding calculations. Note that since the 1988 Constitution, municipalities were obliged to spend at least 25 per cent of collected taxes on education-related services (art. 212).

In the health front, required minimum investment levels combined with conditioning transfers of federal resources to the supply of specific services raised ambulatory and family health care, as well as total health expenditures, and lowered funding inequalities across the country (Vazquez 2014). In the education domain, Fundef led to the expansion of enrollment and reduction in intra-state per pupil spending inequality (Vazquez 2014). Nonetheless, findings have been ambivalent on the association between municipalization and educational outcomes - for instance, student performance at standardised tests (Leme, Paredes $\&$ Souza 2009; Ceneviva 2012). Taking Prova Brasil ${ }^{6}$ scores as the dependent variable, Domingos, Silva and Souza (2013) found no statistical effect of municipality spending, while Amaral and Menezes-Filho (2008) observed a positive and significant effect only for the communities with top performance. One potential explanation formulated by the latter authors is that a certain level of preexisting managerial capability is required to transform additional resources into quality education. Along the same lines, Diaz (2012) was unable to detect an impact of local expenditures in education on IDEB (Índice de Desenvolvimento da Educação Básica, the Basic Education Development Index), a composite measure that combines both student promotion and learning rates. On the other hand, Gonçalves and França (2010), Amaral (2011) and Kroth and Gonçalves (2014) observed a positive influence of local spending on student performance. From a rather different viewpoint, Soares and Alves (2013) estimated school and municipality effects on Prova Brasil scores as the residuals of a hierarchical linear model. These effect estimates were poorly correlated with both per-student costs and the municipality socioeconomic status. Such a result indicates the existence of differences among local school systems (potentially regarding more or less adjusted management policies and instructional methods) that should not be confused with other, more visible cross-municipality disparities.

Decentralisation of public policy created a heightened need for professionalisation of local public management. To learn about both personnel technical qualification and potential obstacles to the institutional consolidation of local bureaucracies, Veloso et al. (2011) surveyed public managers from 194 city halls of seven Brazilian states. Inspired by the Government Performance Project (Ingraham, Joyce \& Donahue 2003; Ingraham 2007), which assessed the public management capacity of federal agencies, state governments, counties and large cities in the United States, the survey addressed four management capacity components, or subsystems: financial, capital, people, and information technology. Veloso et al. (2011) define management capacity as the competence of a local Executive to meet its goals and legal obligations, according to the public interest, efficiently and efficaciously, deploying available resources through adequate management instruments; the concept encompasses the ability to coordinate efforts with other governments and partners too. Some of Veloso et al. (2011) findings include a high level of financial management outsourcing 


\section{III.3. Local budgets}

7 Brollo and Nannicini (2012, p.749) explain that "[a]lthough mayors must make some effort to apply for these discretionary transfers, the legislative and the executive play an important role in defining their precise allocation. The support of a federal deputy and the final consent of the president are crucial ingredients of the allocation mechanism." (which the authors deem a potential threat to sustained good fiscal performance); poor technical qualification of the teams in charge of capital investments; and ample disparities in people management strategies.

Fundeb and SUS-related intergovernmental transfers are only two of several funding sources for local governments. Soares and Melo (2016) group local revenues as follows:

a) Those collected directly by municipalities (own revenues), mostly derived from property taxes and taxation of professional services;

b) Constitutionally mandated transfers, such as Fundo de Participação dos Municípios (FPM, which redistributes the federal income tax and the tax on manufactured products), municipalities' share of the state-level value-added and vehicle taxes (cotas-partes), and Fundeb;

c) SUS-related transfers;

d) Other legally mandated transfers, including some earmarked resources (e.g., from the Fundo Nacional de Desenvolvimento da Educação, the National Fund for Education Development), and oil royalties;

e) Discretionary transfers from federal, state or other municipalities' budgets. ${ }^{7}$

Soares and Melo (2016) classify these five main sources according to their associated level of fiscal autonomy and potential to reduce inequalities. Own revenues enjoy high autonomy and low redistributive potential since they reproduce in public coffers the vigour of each local urban economy. That is a particularly relevant point since the present work focuses on communities whose economy has grown less than expected. If performance on social indicators exceeds expectation, and if national norms concerning fiscal federalism are homogeneously enforced, two of the possible accounts would be that these municipalities are levying more of their citizens and/or better spending their revenues. In a scenario of an economic downturn, the more dependent own revenues are on the household income levels (e.g., the more reliant on services versus property tax), the more acute would the tax burden be on family budgets, all else constant, ultimately threatening families' HD-enhancing consumption. As per the second explanation, the increased share of municipal taxes could imply stronger state capacities (e.g., those involved in keeping taxpayer registries up-to-date, collecting outstanding balance). From this viewpoint, Soares and Melo (2016) use own collections as a proxy for both municipality wealth and technical capabilities; Marenco, Strohschoen and Joner (2017) observed that in municipalities where more than 15 per cent of public servants are college graduates, the odds that the property tax' share of total revenues is larger than one-fifth are 80 per cent higher.

Among the constitutionally mandated flows, the FPM was designed as a redistributive fund, whereas state-level cotas-partes apportion sums proportionate to each municipality's contribution to the total collected; like Fundef, Fundeb was meant to be redistributive, especially within states and, in contrast to FPM and cotas-partes, is earmarked. SUS transfers and most of the other legally imposed ones are redistributive by nature; observe that source d) comprises both earmarked and freely allocated funds. Finally, because discretionary transfers are intended to support specific projects pre-approved by the ceding government (such as building bridges and water and sewer systems, purchasing ambulances), they offer little autonomy, and their redistributive potential is yet to be determined. Available evidence indicates that federal discretionary trans- 
${ }^{8}$ Veloso et al. (2011) highlight an imbalance between revenue potential and policy demands: the smaller municipalities benefit from constitutional transfers more than proportionately, although their policy demands tend to be of lesser complexity than those of the major cities. The latter rely on their own taxation and cotas-partes, however, face enormous demands. Medium size municipalities enjoy neither redistribution nor a large taxpayer base.

${ }^{9}$ Services offered by organisations of the civil society tend to be HD-enhancing (Ranis, Stewart \& Ramirez 2000). It is not different in Brazil, where nonstate providers share de facto responsibility for main programs, and receive discretionary transfers to fund welfare services, typically (Bueno 2017).

${ }^{10}$ The idea behind the name is that "money sticks to where it hits," as first stated by Marshall (1989, p.4), explain Dollery and Worthington (1995, p.23).

\footnotetext{
${ }^{11}$ Such preconditions make grant application expensive and skilled labor intensive; small, poorer, communities will hardly amass the technical prerequisites to obtain a federal discretionary transfer without help (Soares \& Melo 2016).
}

fers favour municipalities with a higher proportion of own collection (Soares \& Melo 2016); these tend to be the bigger cities. ${ }^{8}$

Nunes (2015) explores the patterns and rationale of federal executive, discretionary transfers in countries with varying levels of centralization. Data from Latin America indicate that the more decentralized the nation, the more likely that these transfers favor municipalities governed by co-partisan mayors, even after controlling for a series of alternative explanations, including targeting poverty alleviation. Drawing findings from a regression discontinuity design applied to the Brazilian case, Brollo and Nannicini (2012, p.759) had also found a heavy political motivation to these transfers, notably "aimed at penalizing unaligned municipalities in which mayors belonging to the opposition coalition won by a narrow margin."

Nonetheless, there seems to exist other goals guiding allocation of discretionary transfers. Bueno (2017) identified a bypassing strategy, by which central government distributes resources to municipalities with unaligned mayors through transfers to nonstate public service providers. ${ }^{9}$ Such transfers are even less visible to voters than are those to mayors, the former incurring lesser of a "credit highjacking" risk. Beyond partisan alignment, incumbents (presidents, governors) care about boosting voters' welfare, gaining legislative support, mobilising swing voters, and even exchanging transfers for campaign contributions, explains Bueno (2017).

Efficiency in the application of intergovernmental transfers is most certainly a concern in a system where average municipality's share of own revenues is no larger than 12 per cent of the total budget, warn Costa and Castelar (2015, based on 1999 to 2009 data). These authors set out to test the flypaper hypothesis, ${ }^{10}$ which predicts unconditional grants to "increase public expenditures by more than an equivalent increase in income from other sources," saving the popularity cost of taxing one's own constituency and opening space for less rigorous fiscal policies. Costa \& Castelar (2015) found no evidence of the flypaper effect in Brazilian municipalities, even after analysing different expenditure quantiles.

While the flypaper hypothesis posits lower fiscal responsibility the larger the share of transfers, one has to consider another narrative, valid to discretionary transfers in particular. To be granted, these transfers require grantee municipalities to elaborate a work plan for the intervention being funded, many times involving an engineering project, an environmental permit and other documents necessary for public works, thus potentially increasing room for accountabil ity. ${ }^{11}$ Beyond that, Bertholini, Pereira and Rennó $(2018,9)$ point that discretionary transfers may be a somewhat efficient form of pork because interested politicians will closely monitor project execution, making sure that "promises will be accomplished to credibly claim credit for them." These authors found that transfers originated from legislator-authored amendments to Brazilian central government's annual budgets can generate social and economic inclusion; however, effects tend to dissipate over time, potentially due to policy investments' diminishing returns and inflow concentration into specific locales.

III.4. Brazil's flagship conditional cash transfer

Programa Bolsa Família (PBF) is a federal conditional cash transfer initiated in 2004 that benefits around 14 million families across the country. Devised during President Luiz Inácio Lula da Silva's first term, PBF replaced and integrated a series of other transfers. As a conditional cash transfer, PBF seeks to a) reduce current poverty and inequality, by providing a minimal income inflow to low-income families; and b) break the inter-generational transmission of poverty, by establishing incentives for these families to invest in human capital. 
Transfers are conditioned on beneficiary compliance with requirements (conditionalities), such as school attendance, immunisation, prenatal visits, and participation in nutritional programs.

PBF eligible families are identified according to household per capita income (no more than R \$ 170 monthly, approximately US\$ 50 in 2017 values) and household composition. A portion of the benefit varies according to the number of children and adolescents, pregnant or nursing women, and the per capita income of extremely low-income families (those living with less than $\mathrm{R} \$$ 85, even after receiving the regular PBF transfers). In December 2017, the average PBF benefit was about R $\$ 180$ per family (MDS 2018).

A single registry (Cadastro Único) contains information about current and potential PBF beneficiary families. Municipalities inscribe families (who actively register or are reached out), feeding Cadastro Único with self-declared data about their means, household composition, etc.; this registry is periodically updated and checked against official records, like those related to job participation. Proper maintenance of the database is critical in the reduction of gaps and duplications and in avoiding fraud.

Throughout the last decade, several impact studies have attested that PBF has helped improving living conditions. In particular, income transfers account for 24 per cent of the per capita income inequality reduction between 1995 and 2006, estimated Silveira Neto (2010). After surveying numerous impact studies, Jannuzzi and Pinto (2013) ascertained favourable effects of PBF over a range of socioeconomic indicators, such as increased school attendance, improved performance at large-scale tests, reduced grade retention and child labour. There has also been detected a decline in acute malnutrition and infant mortality, and a rise in immunisation rates, pre-natal care and birth weight. As far as the job market, evidence dismisses the hypothesis of a lowered labour supply on the part of beneficiaries, except for women with children. Furthermore, women - who comprise the almost totality of family members entitled to withdrawal the cash transfers - show elevated decision power in household allocation choices (e.g., regarding the purchase of durable goods, medicines, and clothing, as compared to nonbeneficiaries), which helps to reduce intra-family gender inequalities through empowering.

III.5. Learnings from the literature and proposed argument

The above search for influences over HD has spread to different disciplines (Economics, Political Science, Education, Public Health), encompassing a great variety of references and causal claims. To organise the stated arguments and assist modelling, Chart 1 presents an inventory of such influences. Given the plethora of factors interfering with one's health and schooling, not to mention the interactions between such factors, this list is not exhaustive; on the contrary, it aims to register only the main associations explored by the reviewed literature.

The main argument tested in the analyses ahead is that public policy from central and local governments can have substantive effects on HD. In particular, variation in discretionary transfers from the federal and state governments to municipalities, and the HD-oriented spending of local administrations, are expected to display a positive effect on HD, independently of the local economy's vigor. In this sense, social spending could help counteract income fluctuations' negative effects on living conditions. 
Chart 1 - Influences over HD that have been identified in the reviewed literature

\begin{tabular}{|c|c|c|}
\hline Source & Influence over HD & References \\
\hline \multirow[t]{7}{*}{ Families } & Resource availability & \\
\hline & Income level & $\begin{array}{l}\text { Baldacci et al. (2008); Ranis \& Stewart (2001); Ranis, Stewart } \\
\text { \& Ramirez (2000); Suri et al. (2011) }\end{array}$ \\
\hline & Income inequality & Kenny (2005); Suri et al. (2011) \\
\hline & Resource application & \\
\hline & Gender of household head & Ranis \& Steward (2001); Ranis, Stewart \& Ramirez (2000) \\
\hline & Schooling of household head & Kenny $(2005,2009)$ \\
\hline & Women's schooling & Ranis \& Stewart (2001); Schultz (2002) \\
\hline \multirow[t]{7}{*}{ Governments } & Resource availability & \\
\hline & Own collection & Soares \& Melo (2016); Veloso et al. (2011) \\
\hline & Intergovernmental transfers & $\begin{array}{l}\text { Bertholini, Pereira \& Rennó (2018); Brollo \& Nannicini } \\
\text { (2012); Bueno (2017); Nunes (2015); Soares \& Melo (2016) }\end{array}$ \\
\hline & $\begin{array}{l}\text { State capacity (e.g., to collect taxes, apply } \\
\text { for grants) }\end{array}$ & $\begin{array}{l}\text { Ingraham (2007); Ingraham, Joyce \& Donahue (2003); } \\
\text { Marenco, Strohschoen \& Joner (2017); Soares \& Melo (2016); } \\
\text { Veloso et al. (2011) }\end{array}$ \\
\hline & Resource application & \\
\hline & $\begin{array}{l}\text { Distribution of efforts across programs } \\
\text { (those HD-focused or otherwise) }\end{array}$ & $\begin{array}{l}\text { Baldacci et al. (2008); Jannuzzi \& Pinto (2013); Ranis \& Stew- } \\
\text { art (2001); Silveira Neto (2010); Suri et al. (2011) }\end{array}$ \\
\hline & $\begin{array}{l}\text { State capacity (to formulate and imple- } \\
\text { ment well adjusted, efficient policies) }\end{array}$ & $\begin{array}{l}\text { Amaral \& Menezes-Filho (2008); Baldacci et al. (2008); Costa } \\
\text { \& Castelar (2015); Ingraham (2007); Ingraham, Joyce \& } \\
\text { Donahue (2003); Soares \& Alves (2013); Veloso et al. (2011) }\end{array}$ \\
\hline \multirow[t]{2}{*}{ Civil society } & Resource availability & $\begin{array}{l}\text { Bueno (2017); Ranis \& Steward (2001); Ranis, Stewart \& } \\
\text { Ramirez (2000) }\end{array}$ \\
\hline & Resource application & \\
\hline \multirow[t]{6}{*}{ Initial context } & Vigor of local and national economies & Ranis \& Steward (2001); Ranis, Stewart \& Ramirez (2000) \\
\hline & Social capital & Ranis \& Stewart (2001) \\
\hline & Available technologies & Cutler, Deaton \& Lleras-Muney (2006) \\
\hline & $\begin{array}{l}\text { Strength of associations between HD in- } \\
\text { puts }\end{array}$ & $\begin{array}{l}\text { Baldacci et al. (2008); Kenny }(2005,2009) \text {; Ranis \& Steward } \\
\text { (2001) }\end{array}$ \\
\hline & $\begin{array}{l}\text { Demand for HD (age profile, level of ur- } \\
\text { banization, population size etc.) }\end{array}$ & $\begin{array}{l}\text { Gupta, Verhoeven \& Tingson (2002); Kenny (2005); } \\
\text { Mayer-Foulkes (2010); Veloso et al. (2011) }\end{array}$ \\
\hline & HD levels & $\begin{array}{l}\text { Jordá \& Sarabia (2015a, 2015b); Karruz \& Vale (2015); Kenny } \\
\text { (2005); Kónya (2011); Kónya \& Guisan (2008); } \\
\text { Mayer-Foulkes (2010); Newmayer (2003); Noorbakhsh (2006) }\end{array}$ \\
\hline
\end{tabular}

Source: The author.

\section{Data and methodology}

\section{IV.1. Data}

${ }_{12}$ The MHDI combines three dimension-specific indexes. Income MHDI is based on the average income of all inhabitants of the municipality. Longevity MHDI is a function of life expectancy. Schooling MHDI blends five indicators, regarding enrollment and
The empirical analysis ahead draws information from four sources. Data on 2000 and 2010 MHDI, its dimension-specific indexes ${ }^{12}$ and other demographic and socioeconomic indicators were extracted from Atlas do Desenvolvimento Humano no Brasil - an online database built by the Brazilian United Nations Development Programme office and partners, assembling HD-related data for multiple subnational territorial units. Local budgetary information was retrieved from Finbra - Finanças do Brasil, which publicises revenues and implemented yearly budget values as per declared by municipalities to the Secretaria do Tesouro Nacional, a division of the Brazilian Finance Ministry. Other bud- 
middle and high school graduation rates. All three dimension indicators range from zero to one (the greater, the better the HD). getary indicators come from Rio de Janeiro's Federation of Industries, Sistema Firjan. The fourth source is the website of the Ministério do Desenvolvimento Social (Ministry of Social Development), from which data on PBF were downloaded through the platform Matriz de Informação Social (the Social Information Matrix).

All these pieces of data were combined and organised as a panel whose unit of analysis is municipality-year, covering the 5.565 existing municipalities in 2010. Years include 2000 and 2010, except for budgetary and PBF variables for which decade averages were calculated based on yearly values.

Two major analytical steps are undertaken in this work. First, identification of the municipalities with slower-than-expected income growth and, within these, those with either above- or below-expected trends in schooling and longevity.

Grouping municipalities according to changes in their social indicators is a variation of the approach used by Ranis, Stewart and Ramirez (2000) and Suri et al. (2011). Both studies classify the trajectory of developing countries in the second half of the twentieth century into four categories: (i) virtuous cycle, for those showing above-average advancements in both HD and EG; (ii) vicious cycle, for countries performing below average in both dimensions; (iii) EG-lopsided, for cases with worse-than-average changes in HD but above-average EG; and (iv) HD-lopsided, the symmetrical category for (iii). Empirical evidence indicates that "policies to improve HD must precede or at least complement growth-oriented policies if growth is to be accelerated and sustainable" (Suri et al., 2011, 519), a finding with direct implications over policy sequencing.

The present study focuses on categories (ii) and (iv), where EG is less than expected. Specifically, it aims at finding out what sets (ii) and (iv) apart. Differently from Ranis, Stewart and Ramirez (2000) and Suri et al. (2011), here the HD dimension is broken down into the longevity and schooling components, each with its own (above or below expectation) trajectory over the 2000s. This approach allows for more granularity in the investigation on potential influences of governments' spending on health and education standards.

A well-documented pattern of HD-convergence, discussed earlier, provides the theoretical grounds for estimating annual growth rates for each MHDI dimension. Equation (I), a simple convergence model adapted from Jordá and Sarabia (2015a), was applied to calculate unconditional convergence rates and the respective predicted growth rate for municipality i. Y represents each of the MHDI dimensions.

$$
\frac{1}{10} \log \left(\frac{Y 2010_{i}}{Y 2000_{i}}\right)=\alpha+\beta \log \left(2000_{i}\right)+\varepsilon_{i}(\mathrm{I})
$$

Figure 1, below, portrays scatter plots of the convergence analysis' dependent and independent variables, as well as of the general MHDI. A negative slope is visible in each panel, pointing out that the larger the 2000 value, the smaller the expected 2000-2010 growth, all else constant.

All four indicators analysed show a convergence pattern, as per the estimated slope coefficients (Table 1). Convergence seems most intense in schooling and least in income; still, initial income dimension levels solely explain 53.9 per cent of variation around the mean. All else constant, a one per cent increase in 2000 Income MHDI associates with a 0.029 per cent decrease in its expected annualised 2010-2000 ratio. 
Figure 1 - Growth rates by initial value: MHDI and its dimensions (2000-2010)

1.a) MHDI

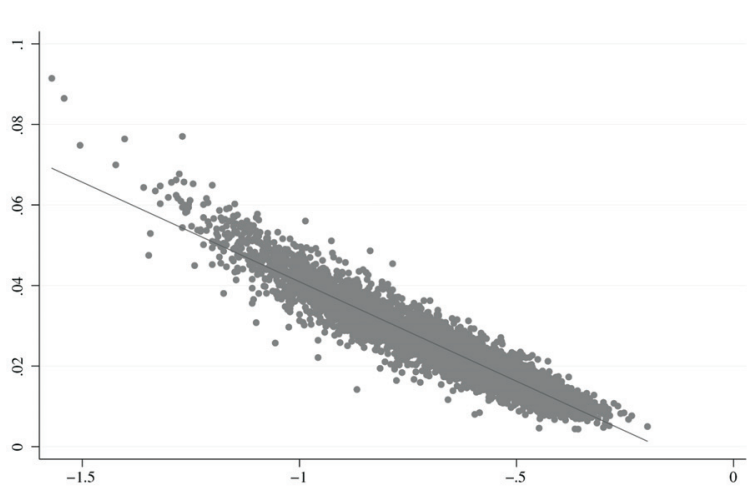

$\log 2000 \mathrm{MHDI}$

- Annual log of MHDI 2000-2010 growth rate — Fitted values 1.b) Income MHDI

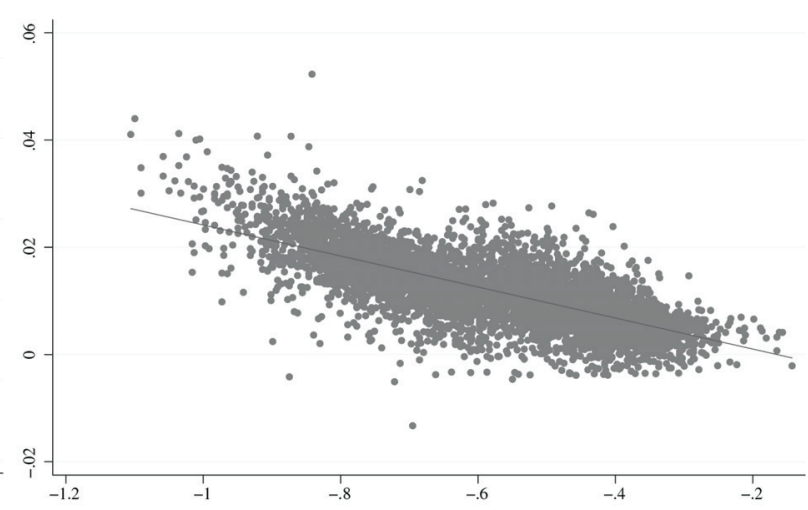

Log 2000 Income MHDI

- Annual log of Income MHDI 2000-2010 growth rate _ Fitted values

\section{1.c) Longevity MHDI}

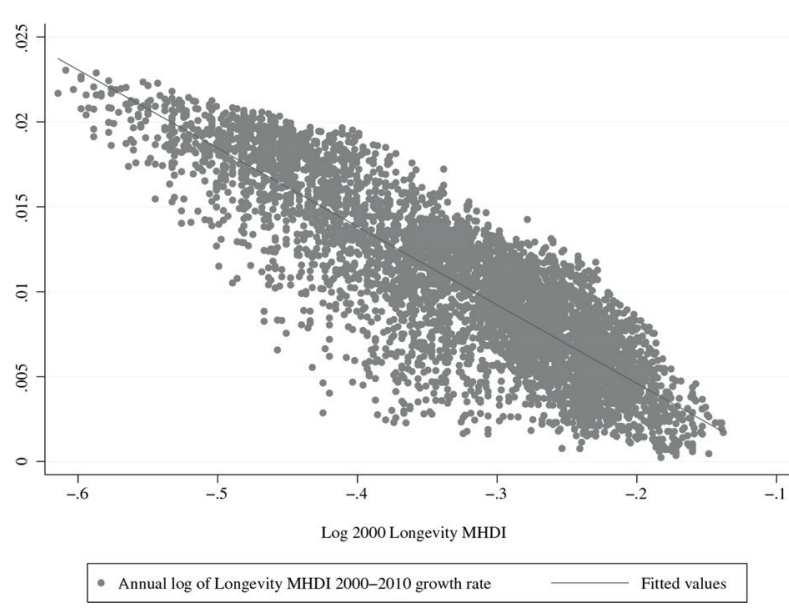

1.d) Schooling MHDI

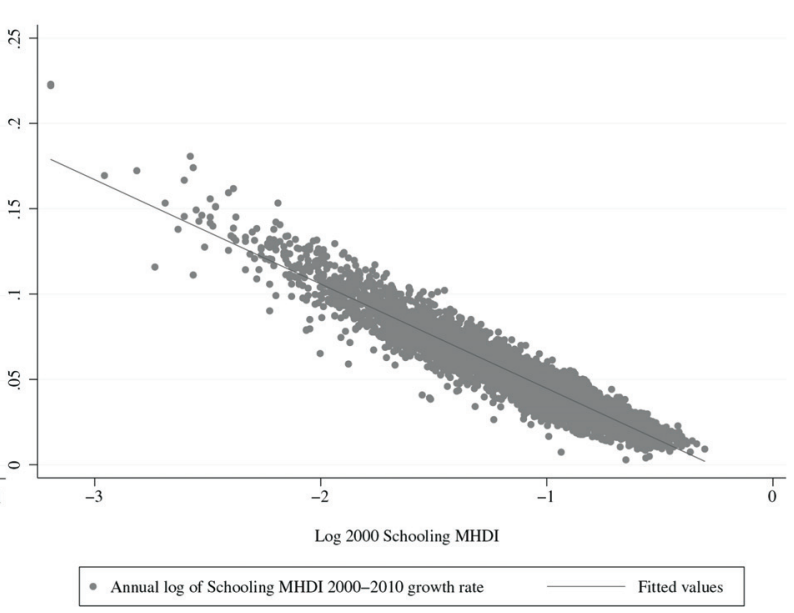

Note: $\mathrm{N}=5,565$ municipalities in all four panels (1.a to 1.d).

Source: The author, based on raw data from Atlas do Desenvolvimento Humano no Brasil.

Municipalities with 2000-2010 observed income growth rates smaller than the lower limit value of a 95 per cent confidence interval around the predicted dependent variable are kept in the working sample, all other ones being removed from it. Following the same tactics, are then excluded localities whose observed longevity (schooling) growth rate falls within the estimated confidence interval for the respective dimension. The sample is reduced to $2,482 \mathrm{mu}-$ nicipalities, each classified in one of the four groups described in Chart 2.

Group 1 congregates cases where all three dimensions grew less than foreseen and are nicknamed double social loss group. Group 4, on the other extreme, is the double social gain one. Groups 2 and 3 combine some social gain with some social loss. Because no arbitrary judgment regarding the relative values of longevity and schooling are made, it is not possible to order the four groups based on their desirability, although 1 and 4 are the least and most favourable clusters. 
Table 1 - Regression estimates from the convergence models (2000-2010)

\begin{tabular}{|c|c|c|c|c|}
\hline Variable & MHDI & Income MHDI & Longevity MHDI & Schooling MHDI \\
\hline \multirow[t]{2}{*}{ Log 2000 MHDI } & $-0.049 *$ & & & \\
\hline & $(0.000)$ & & & \\
\hline \multirow[t]{2}{*}{ Log 2000 Income MHDI } & & $-0.029 *$ & & \\
\hline & & $(0.000)$ & & \\
\hline \multirow[t]{2}{*}{ Log 2000 Longevity MHDI } & & & $-0.046^{*}$ & \\
\hline & & & $(0.000)$ & \\
\hline \multirow[t]{2}{*}{ Log 2000 Schooling MHDI } & & & & $-0.061 *$ \\
\hline & & & & $(0.000)$ \\
\hline \multirow[t]{2}{*}{ Constant } & $-0.008 *$ & $-0.005^{*}$ & $-0.005^{*}$ & $-0.016^{*}$ \\
\hline & $(0.000)$ & $(0.000)$ & $(0.000)$ & $(0.000)$ \\
\hline Observations & 5,565 & 5,565 & 5,565 & 5,565 \\
\hline $\mathrm{R}^{2}$ & 0.907 & 0.539 & 0.734 & 0.914 \\
\hline
\end{tabular}

Notes: Robust standard errors are presented in parentheses. ${ }^{*} \mathrm{p}<0.01$.

Source: The author, based on raw data from Atlas do Desenvolvimento Humano no Brasil.

Chart 2 - Grouping of municipalities

\begin{tabular}{lcccccc}
\hline \multirow{2}{*}{ Group } & \multicolumn{2}{c}{ Observed 2010 MHDI dimension* } & & \multicolumn{2}{c}{ Sample size } \\
\cline { 2 - 3 } \cline { 5 - 6 } & Income & Longevity & Schooling & & $\begin{array}{c}\text { Initial n (\%) } \\
\text { Working n } \\
(\%) * *\end{array}$ \\
\hline 1 - Double social loss & Below lower & Below lower & Below lower & & $667(27)$ & $622(27)$ \\
2 - Longevity gain, schooling loss & & Above upper & & $676(27)$ & $642(27)$ \\
3 - Longevity loss, schooling gain & & Below lower & Above upper & & $566(23)$ & $539(23)$ \\
$4-$ Double social gain & Above upper & & $573(23)$ & $542(23)$ \\
All four groups & & As detailed above & & $2,482(100)$ & $2,345(100)$ \\
\hline
\end{tabular}

Source: The author, based on raw data from Atlas do Desenvolvimento Humano no Brasil

Notes: * In relation to the bounds of the respective dimension's confidence interval, calculated through the convergence analysis. ** With complete budgetary data (see subsection IV.6 for details).

\section{IV.3. Multivariate modelling}

The second analytical step gets to the core goal of this work: to map characteristics of family and policy environments, as well as of the demand for social services, that seem to associate with an elevated chance to escape the double social loss situation. To that pursuit, a multinomial logit model is calculated as in Equation (II).

$$
\log \left(\frac{\pi_{i j}}{\pi_{i J}}\right)=\alpha_{j}+\beta_{i j} X_{i}+\varepsilon_{i j}(\mathrm{II})
$$

Multiple equations ( $\mathrm{J}-1)$ are estimated, being $\mathrm{J}$ here equal four, the number of groups. The dependent variable is the log-odds of falling in group $\mathrm{j}$ relative to $\mathrm{J}$, the referent one - set to be the double social loss group. A constant $(\alpha)$ and a series of linear slope coefficients $(\beta)$ are predicted in each equation. Vector $X$ contains the independent variables (see Chart 3), many of which are paired with a respective measure of change within the 2000s (to account, where possible, for variation within the relatively long ten-year time window). $\mathrm{X}$ also includes a 
13 An alternative specification was tried, with random intercepts at the state level. Random intercept estimates are directionally similar; they are displayed in Appendix

Table 1 for reference. set of dummies for states, to control for unobserved cross-state heterogeneity that is constant over the $2000-2010$ period: ${ }^{13} \varepsilon$ is the stochastic term. Robust standard errors are estimated to tackle heteroscedasticity. By exponentiating the estimated parameters, one can project the influence of each explanatory variable in the risk of pertaining to a given group relative to the referent one, all else constant. The relative risk ratio (RRR) consists of a ratio of two probabilities, in this case, the probability to belonging to group $j\left(\pi_{i j}\right)$ over the probability to belonging to the double social loss one $\left(\pi_{i J}\right) ; \mathrm{e}^{\hat{\beta}}$ is interpreted as a multiplicative effect on RRR.

All else constant, the expectation is that municipalities with a lower income or a higher Gini coefficient (a measure of per capita household income concen-

Chart 3 - Explanatory variables in the multinomial logit model

\begin{tabular}{|c|c|c|c|c|}
\hline Source & Influence over HD & Variable (level) & Variable (as change) & Raw data \\
\hline \multirow[t]{3}{*}{ Families } & Income level & $\begin{array}{l}+2000 \text { Average per capita } \\
\text { income }\end{array}$ & $2000-2010 \%$ change & $\begin{array}{l}\text { Atlas do Desenvol-vimento } \\
\text { Humano no Brasil }\end{array}$ \\
\hline & Income inequality & - 2000 Gini $(0-100)$ & 2000-2010 change & \\
\hline & $\begin{array}{l}\text { Schooling of household } \\
\text { head }\end{array}$ & $\begin{array}{l}\text { - } 2000 \% \text { of children in } \\
\text { households with no middle } \\
\text { school graduates }\end{array}$ & 2000-2010 change & \\
\hline \multirow[t]{9}{*}{ Govs. } & Resource availability & $\begin{array}{l}+2000 \text { per capita total rev- } \\
\text { enue }\end{array}$ & $\begin{array}{l}2000-2010 \text { average y-to-y } \\
\% \text { change }\end{array}$ & $\begin{array}{l}\text { Finbra - Finanças do } \\
\text { Brasil }\end{array}$ \\
\hline & Own collection & $\begin{array}{l}\text { + Average } 2000-2010 \% \text { of } \\
\text { municipality own revenue } \\
\text { collection }\end{array}$ & $\begin{array}{l}\text { 2000-2010 average y-to-y } \\
\text { change }\end{array}$ & \\
\hline & Intergov. transfers & $\begin{array}{l}+ \text { Average } 2002-2010 \% \text { of } \\
\text { federal, state discretionary } \\
\text { transfers* }\end{array}$ & $\begin{array}{l}2002-2010 \text { average } y-t o-y \\
\text { change* }\end{array}$ & \\
\hline & $\begin{array}{l}\text { State capacity (e.g., to col- } \\
\text { lect taxes, apply for grants) }\end{array}$ & $\begin{array}{l}+ \text { Average } 2006-2010 \\
\text { IFGF }(0-100)^{* *}\end{array}$ & $\begin{array}{l}\text { 2006-2010 average y-to-y } \\
\text { change }\end{array}$ & Sistema Firjan \\
\hline & $\begin{array}{l}\text { Distribution of efforts } \\
\text { across programs (those } \\
\text { HD-focused or otherwise) }\end{array}$ & $\begin{array}{l}+ \text { Average } 2000-2010 \% \text { of } \\
\text { total expenditures spent in } \\
\text { education and culture }\end{array}$ & $\begin{array}{l}\text { 2000-2010 average y-to-y } \\
\text { change }\end{array}$ & $\begin{array}{l}\text { Finbra - Finanças do } \\
\text { Brasil }\end{array}$ \\
\hline & & $\begin{array}{l}+ \text { Average } 2000-2010 \% \text { of } \\
\text { total expenditures spent in } \\
\text { health and sanitation }\end{array}$ & $\begin{array}{l}\text { 2000-2010 average y-to-y } \\
\text { change }\end{array}$ & \\
\hline & & $\begin{array}{l}\text { + Average } 2004-2010 \% \text { of } \\
\text { PBF coverage }\end{array}$ & $\begin{array}{l}\text { 2004-2010 average y-to-y } \\
\text { change }\end{array}$ & $\begin{array}{l}\text { Matriz de Informação So- } \\
\text { cial }\end{array}$ \\
\hline & $\begin{array}{l}\text { State capacity (to formu- } \\
\text { late and implement }\end{array}$ & $\begin{array}{l}\text { + Average 2007-2010 } \\
\text { IGD*** }\end{array}$ & $\begin{array}{l}\text { 2007-2010 average y-to-y } \\
\text { change }\end{array}$ & \\
\hline & & $\begin{array}{l}\text { + Average } 2006-2010 \\
\text { IFGF }(0-100)^{* *}\end{array}$ & $\begin{array}{l}2006-2010 \text { average y-to-y } \\
\text { change }\end{array}$ & Sistema Firjan \\
\hline \multirow[t]{5}{*}{$\begin{array}{l}\text { Initial } \\
\text { context }\end{array}$} & $\begin{array}{l}\text { Demand for HD (age pro- } \\
\text { file, level of urbaniza- }\end{array}$ & $\begin{array}{l}2000 \% \text { of } 6-17 \text { year-old } \\
\text { population }\end{array}$ & 2000-2010 change & $\begin{array}{l}\text { Atlas do Desenvolvimento } \\
\text { Humano no Brasil }\end{array}$ \\
\hline & tion, population size etc.) & $\begin{array}{l}+2000 \% \text { of population liv- } \\
\text { ing in urban areas }\end{array}$ & 2000-2010 change & \\
\hline & & $\begin{array}{l}2000 \text { Population: From } \\
20,001 \text { to } 50,000\end{array}$ & $\begin{array}{l}2000-2010 \% \text { change in to- } \\
\text { tal population }\end{array}$ & \\
\hline & & $\begin{array}{l}2000 \text { Population: From } \\
50,001 \text { to } 100,000\end{array}$ & $\begin{array}{l}2000-2010 \% \text { change in to- } \\
\text { tal population }\end{array}$ & \\
\hline & & $\begin{array}{l}2000 \text { Population: Above } \\
100,000\end{array}$ & $\begin{array}{l}2000-2010 \% \text { change in to- } \\
\text { tal population }\end{array}$ & \\
\hline
\end{tabular}




\begin{tabular}{|c|c|c|c|c|}
\hline Source & Influence over HD & Variable (level) & Variable (as change) & Raw data \\
\hline & \multirow[t]{2}{*}{ HD levels } & $\begin{array}{l}\text { + } 2000 \text { Longevity quartile: } \\
\text { Lowest }\end{array}$ & & \\
\hline & & $\begin{array}{l}+2000 \text { Schooling quartile: } \\
\text { Lowest }\end{array}$ & & \\
\hline
\end{tabular}

Source: The author.

Notes: $(0-100)=$ In a 0 to 100 scale. $*$ Due to differences in the Finbra accounting scheme over the years, no comparable values are available for 2000 and 2001. ** 2006 is the earliest year for which IFGF is available. *** 2007 is the earliest year for which IGD is available. - Negative hypothesized influence over HD; + Positive hypothesized influence over HD; for change variables, hypotheses are the same as those for the respective level.

tration) will suffer more from a slow economic scenario since many families will have insufficient resources to cater for their education and health care needs. The higher the per cent of children (up to 14 years old) living in households without a middle school graduate, the lower the expected advancements in health and education. Such variable reports the share of children in households where the cultural capital is underprivileged, with potential implications on adults' employability and resourcefulness - e.g., in helping the schooling of children and fostering their health.

The second set of covariates concerns the potential of local governments to execute public policies, through the lenses of resource availability and application. It controls for per capita total revenues in 2000 , as well as by its average year-to-year per cent growth rate. Importantly, given the constitutional floor percentages to be engaged in education and health, the higher the total revenue, the higher the nominal values deployed in such functions. Total revenues are then broken down considering: a) how much originates from own collection, and b) how much comes from the federal and state governments in the form of discretionary transfers. The hypothesis is that a) positively correlates with town hall's capability to levy taxes (e.g., via higher tax burden, more efficient collection), which could indicate a highly skilled bureaucracy (Marenco, Strohschoen \& Joner 2017) - similarly capable of executing well-adjusted social policies. As far as b), the hypothesis is also in the positive side: while discretionary transfers are not necessarily redistributive, they require a good level of bureaucratic resourcefulness from local governments, and here too an expectation regarding overall administrative capability is tenable; not the least, the very projects funded by discretionary transfers may be HD-enhancing (Bertholini, Pereira \& Rennó 2018). From the expenditures perspective, local investment in education, culture, health and sanitation should positively influence social indicators, both directly by the primary function and indirectly, through the effects of one's good education on health status (and vice versa).

Alongside the detailed budgetary variables, the Índice Firjan de Gestão Fiscal (IFGF, the Firjan Fiscal Management Index), calculated by the Federation of Industries of the State of Rio de Janeiro, is taken both as a measure of resource availability and as a proxy for state capacity (e.g., to collect taxes, formulate efficient policies). IFGF was conceived to portray challenges faced by local administrations across the country, especially those regarding resource insufficiency and the burden of debt. It comprises five indicators, all ranging from zero to one (the greater, the better the fiscal management), just like the composite IFGF itself. IFGF touches upon the following dimensions: capacity to obtain revenue (own collection); capacity to make investments; the degree of budgetary rigidity (proportion of revenues used to pay personnel); fund availability to meet short-term obligations; and the cost of long-term debt (Sistema Firjan 2015). 
${ }^{14}$ Because the coverage measure for PBF did suffer methodological modifications through the years, its year-to-year face value comparability is not guaranteed. Still, cross-municipality comparisons are warranted. ${ }^{15}$ IGD is a simple average of four indicators. Two correspond to proportions of families in the Cadastro Único (with complete and coherent information; and who last saw a social worker in less than two years). The other two are the proportions of beneficiary children with complete monitoring of the education and health conditionalities (Soares 2012).

\footnotetext{
${ }^{16}$ Schooling MHDI combines five indicators: per cent of population older than 18 that graduated from middle school; per cent of 18-20 year-olds that graduated from high school; per cent of 5-6 year-olds enrolled in school; per cent of 11-13 year-olds enrolled in the final grades of middle school; and per cent of 15-17 year-olds that graduated from middle school.
}

Additionally, the governments' set of variables includes two measures regarding PBF. One concerns program reach (in relation to the number of target families); by fighting extreme poverty and imposing education and health care conditions to participation, the program is expected to improve HD among the most vulnerable. ${ }^{14}$ The other corresponds to the Índice de Gestão Descentralizada (IGD, the Decentralized Management Index), which should help isolate the influence of PBF coverage from occasional implementation problems (of dated information in the Cadastro Único and faulty conditionality monitoring). IGD was designed to support a performance-based financial incentive paid by PBF to the municipalities. The goal was to encourage local governments to keep Cadastro Único up-to-date and to oversee the meeting of program conditionalities, explain Soares (2012) and Paiva et al. (2016). ${ }^{15}$ IGD ranges from zero to one; the closer to one, the better the PBF management at the local level. Furthermore, as discussed above, beyond the sheer amount of available resources, aspects of quality in their application make a great deal of difference in fostering HD. Quality may refer to more or less adequate choices made among policy alternatives, which entail varying levels of efficiency, efficacy, effectiveness and social justice. It may also regard operational capability to implement the chosen policies, bringing to life expectations written down in intervention proposals and laws. IGD is included as a control variable that also accounts for at least part of the variation in local administrations' competence to devise and execute quality actions.

As far as the demand for education and health services, a younger population imposes a stronger pressure on the primary and secondary schooling system. It may also signal that ageing is less likely due to, for instance, urban violence. Conversely, a larger per cent of 6-17 year-olds may represent a type of demand that is "easier" to serve, since Schooling MHDI indicators of that age bracket mostly regard enrollment, not graduation. ${ }^{16}$ Furthermore, a younger demographic profile may also indicate reduced infant mortality and a prevalence of (cheaper) prophylactic (versus more expensive therapeutic) treatment needs. Similarly, a smaller share of senior citizens demands less of the health care services, especially those to cope with chronic conditions (e.g., high blood pressure, diabetes) and of higher complexity. Because the relationship between per cent of 6-17 year-olds and social progress could defensibly go either way, no specific hypothesis is defined for this covariate.

Moving to the variables that control for the number of inhabitants and their spatial distribution, the more urbanized the municipality, the more likely it is to perform well on HD, as previously discussed. With respect to the sheer size of population, its influence could also go both ways: variety and complexity of demands tend to be lower in smaller localities, however so too tend to be the availability of skilled government staff and response procedures to emerging needs. The controls for initial HD level are expected to return positive coefficients, given the convergence trends explored earlier; to avoid having a proxy of the explained phenomenon among the independent variables, no "change" analogues were defined for these two covariates.

\section{IV.4. Adherence to multinomial logit assumptions}

Multinomial models rest on the independence of irrelevant alternatives (IIA) assumption, which requires that "adding or deleting outcomes does not affect the odds among the remaining outcomes" (Long \& Freese 2001, p.188). To meet IIA, outcome alternatives must be dissimilar and not merely substitutes for one another. This is a somewhat vague advice, and empirical tests developed for IIA will not offer much more guidance. Long and Freese (2001) discourage the use of such tests (e.g., Hausman and the Small-Hsiao) because they often reach 
conflicting results. In this study, given the fact that the four groups do not cover the entire range of possibilities - they do not include municipalities that fall within confidence intervals $-i t$ is argued that these groups are not necessary substitutes.

Another assumption of the multinomial models is that the outcome levels (groups) have no natural ordering. On a HD scale, it is clear that double social loss fares more poorly than double social gain, however relative desirability between the two intermediate groups is much less evident. To test whether the two latter groups should be meshed together - actually, to assess if any pair of groups should be combined - Wald tests were conducted; results (not shown) indicate that none of the four groups should be fused, at the 0.1 per cent level of significance.

IV.5. Identification strategy

The identification strategy for the association between each covariate and the probability that the municipality will fall in a certain group relies on: a) differential levels of the independent variables as a source of variation among municipalities; and b) an extensive set of controls covering demand for HD and initial HD levels. As this work's ambition is to explore associations, not to explain them, such identification strategy is deemed compatible with the present research goals.

A challenge to internal validity is the fact that, concomitantly to the resources and expenses visible in local budgets, state and federal governments are acting through direct investments that affect HD (e.g., expanding the high school system, building/ improving interstate highways). For such investments not to bias estimated parameters, it would require to admit that the former are homogeneously or randomly distributed; unobserved time-invariant cross-state variability is controlled for by a set of dummies for states.

IV.6. The working sample

17 The 137 removed localities are regionally distributed as follows: 14 in Mid-West, 46 in North, 60 in Northeast, 3 in South, and 14 in Southeast. In the initial sample, they represent 7.37, 15.65, 6.70, 1.20 , and 1.65 per cent of municipalities in each region, respectively. Almost all (134) excluded municipalities lacked 2000 total revenue data, while for some of these other budget values were also absent; IFGF was missing for other three localities.

${ }^{18}$ For parsimony, Table 3 does not include the state dummies.

${ }_{19}$ All money figures presented in this work have been adjusted for inflation through the Índice Nacional de Preços ao Consumidor (INPC, the National Consumer Price
For the multinomial estimation, the number of observations is constrained by Finbra - Finanças do Brasil and IFGF data availability, which forces the exclusion of 137 (5.52 per cent) localities from the initial sample $(n=2,482) \cdot{ }^{17} \mathrm{Ta}-$ ble 2 presents the mean value in each group for covariates in the multinomial model and other selected variables, considering the working sample $(\mathrm{n}=2,345){ }^{18}$

The "change" Gini variable depicts (in Table 2) a scenario of decreasing per capita household income inequality over the 2000s. Noteworthy, per cent of children in households with no middle school graduates fell 20 per cent points or more in all four groups. Budgetary indicators tended to change little from one year to the next, except for the per capita total revenues, which grew on average 7.24 per cent each year, net of inflation. ${ }^{19}$ Per cent of own collection revenue and per cent spent in health and sanitation increased by 0.26 and 0.59 per cent point yearly, on average. On the other hand, the share of discretionary transfers and expenditures on education and culture tended to shrink: 0.21 and 0.24 per cent point a year. Initial IFGF components tended to be smaller (greater) in group 1 (group 4) than in the other groups.

In the working sample, age profile seems to have grown older in the 2000s, with a 5.65 per cent point average decline in the per cent of the 6-17-year-old population over the decade. Urbanisation advanced 4.82 per cent points in ten years, on average, while the total population increased 10.19 per cent between 
Table 2 - Means of explanatory and other selected variables, by group

\begin{tabular}{|c|c|c|c|c|c|c|c|c|c|}
\hline \multirow{2}{*}{$\begin{array}{l}\text { Variable } \\
\text { Influence on HD: Families }\end{array}$} & \multirow[t]{2}{*}{$\begin{array}{l}\text { All four } \\
\text { groups }\end{array}$} & \multicolumn{2}{|c|}{ Group 1} & \multicolumn{2}{|c|}{ Group 2} & \multicolumn{2}{|c|}{ Group 3} & \multicolumn{2}{|c|}{ Group 4} \\
\hline & & & & & & & & & \\
\hline 2000 Per capita income (in BRL 10s) & 33,27 & 29,45 & $*$ & 32,32 & & 34,48 & & 37,56 & * \\
\hline $2000-2010 \%$ change in per capita income & 34,18 & 36,20 & $*$ & 33,63 & & 34,23 & & 32,45 & $*$ \\
\hline 2000 Gini $(0-100)$ & 56,48 & 56,25 & & 56,74 & & 56,23 & & 56,68 & \\
\hline 2000-2010 change in Gini (0 - 100) & $-7,10$ & $-6,31$ & $*$ & $-7,31$ & & $-7,33$ & & $-7,53$ & \\
\hline $\begin{array}{l}2000 \% \text { of children in households with no middle school } \\
\text { graduates }\end{array}$ & 64,67 & 67,08 & $*$ & 65,04 & & 64,39 & & 61,74 & * \\
\hline $\begin{array}{l}2000-2010 \text { change in } \% \text { of children in households with no } \\
\text { middle school graduates }\end{array}$ & $-23,18$ & $-19,98$ & $*$ & $-20,32$ & $*$ & $-27,24$ & * & $-26,20$ & * \\
\hline \multicolumn{10}{|l|}{ Influence on HD: Governments } \\
\hline 2000 per capita total revenues (in BRL 10s) & 106,89 & 96,56 & & 91,53 & $*$ & 137,74 & & 106,25 & \\
\hline $\begin{array}{l}\text { Average } 2000-2010 \text { y-to-y \% change in per capita total } \\
\text { revenues }\end{array}$ & 7,24 & 6,79 & & 6,95 & & 6,94 & & 8,41 & \\
\hline $\begin{array}{l}\text { Average } 2000-2010 \% \text { of municipality own collection } \\
\text { revenues }\end{array}$ & 10,60 & 8,85 & * & 10,11 & & 11,33 & * & 12,48 & * \\
\hline $\begin{array}{l}\text { Average } 2000-2010 \text { y-to-y change in } \% \text { of municipality } \\
\text { own collection revenues }\end{array}$ & 0,26 & 0,24 & & 0,27 & & 0,29 & & 0,27 & \\
\hline $\begin{array}{l}\text { Average } 2002-2010 \% \text { of federal + state discretionary } \\
\text { transfers } * *\end{array}$ & 4,80 & 4,54 & $*$ & 4,96 & & 5,04 & & 4,65 & \\
\hline $\begin{array}{l}\text { Average } 2002-2010 \text { y-to-y change in } \% \text { of federal + state } \\
\text { discretionary transfers }\end{array}$ & $-0,21$ & $-0,28$ & & $-0,29$ & & $-0,13$ & & $-0,12$ & $*$ \\
\hline $\begin{array}{l}\text { Average } 2000-2010 \% \text { of total expenditures spent in edu- } \\
\text { cation and culture }\end{array}$ & 32,21 & 32,71 & $*$ & 31,49 & $*$ & 32,97 & * & 31,73 & \\
\hline $\begin{array}{l}\text { Average } 2000-2010 \text { y-to-y change in } \% \text { of total expendi- } \\
\text { tures spent in education and culture }\end{array}$ & $-0,24$ & $-0,25$ & & $-0,31$ & $*$ & $-0,19$ & & $-0,21$ & \\
\hline $\begin{array}{l}\text { Average } 2000-2010 \% \text { of total expenditures spent in } \\
\text { health and sanitation }\end{array}$ & 22,11 & 21,74 & $*$ & 22,13 & & 22,13 & & 22,48 & * \\
\hline $\begin{array}{l}\text { Average } 2000-2010 \text { y-to-y change in } \% \text { of total expendi- } \\
\text { tures spent in health and sanitation }\end{array}$ & 0,59 & 0,58 & & 0,69 & $*$ & 0,50 & $*$ & 0,57 & \\
\hline $\begin{array}{l}\text { Average 2004-2010 \% of Programa Bolsa Familia cover- } \\
\text { age }\end{array}$ & 87,78 & 88,24 & & 89,27 & $*$ & 86,59 & * & 86,67 & \\
\hline $\begin{array}{l}\text { Average 2004-2010 y-to-y change in \% of Programa } \\
\text { Bolsa Familia }\end{array}$ & 5,93 & 6,04 & & 5,61 & $*$ & 6,19 & & 5,95 & \\
\hline Average 2007-2010 IGD (0 - 100) & 76,36 & 77,05 & $*$ & 76,14 & & 76,65 & & 75,56 & * \\
\hline Average $2007-2010$ y-to-y change in IGD $(0-100)$ & 3,29 & 3,63 & $*$ & 3,52 & & 2,99 & & 2,92 & * \\
\hline Average 2006-2010 IFGF (0 - 100) & 48,24 & 45,27 & $*$ & 47,25 & $*$ & 50,06 & * & 51,00 & * \\
\hline Average $2006-2010$ y-to-y change in IFGF (0 - 100) & 0,17 & 0,04 & & 0,39 & & 0,15 & & 0,10 & \\
\hline $\begin{array}{l}\text { Average 2006-2010 IFGF own revenues indicator }(0 \text { - } \\
\text { 100) }\end{array}$ & 20,93 & 17,15 & $*$ & 19,98 & & 22,56 & * & 24,77 & $*$ \\
\hline $\begin{array}{l}\text { Average } 2006-2010 \text { y-to-y change in IFGF own revenues } \\
\text { indicator }(0-100)\end{array}$ & 0,23 & 0,35 & & 0,08 & & 0,27 & & 0,23 & \\
\hline $\begin{array}{l}\text { Average } 2006-2010 \text { IFGF personnel expenditures indica- } \\
\text { tor }(0-100)\end{array}$ & 61,95 & 59,73 & $*$ & 59,88 & $*$ & 63,96 & * & 64,95 & $*$ \\
\hline $\begin{array}{l}\text { Average } 2006-2010 \text { y-to-y change in IFGF personnel ex- } \\
\text { penditures indicator }(0-100)\end{array}$ & $-2,53$ & $-2,86$ & & $-2,22$ & & $-2,45$ & & $-2,60$ & \\
\hline Average 2006-2010 IFGF investments indicator $(0-100)$ & 53,18 & 50,69 & $*$ & 51,65 & $*$ & 56,39 & * & 54,64 & * \\
\hline $\begin{array}{l}\text { Average } 2006-2010 \text { y-to-y change in IFGF investments } \\
\text { indicator }(0-100)\end{array}$ & 0,81 & 1,16 & & 0,91 & & 0,50 & & 0,60 & \\
\hline Average 2006-2010 IFGF liquidity indicator $(0-100)$ & 42,91 & 38,62 & $*$ & 43,76 & & 43,80 & & 45,94 & $*$ \\
\hline
\end{tabular}




\begin{tabular}{|c|c|c|c|c|c|c|c|c|c|}
\hline \multirow{2}{*}{$\begin{array}{l}\text { Variable } \\
\begin{array}{l}\text { Average 2006-2010 y-to-y change in IFGF liquidity indi- } \\
\text { cator }(0 \text { - } 100)\end{array}\end{array}$} & \multirow{2}{*}{$\begin{array}{c}\begin{array}{c}\text { All four } \\
\text { groups }\end{array} \\
2,19\end{array}$} & \multicolumn{2}{|c|}{ Group 1} & \multicolumn{2}{|c|}{ Group 2} & \multicolumn{2}{|c|}{ Group 3} & \multicolumn{2}{|c|}{ Group 4} \\
\hline & & 1,49 & $*$ & 2,60 & & 2,48 & & 2,23 & \\
\hline Average 2006-2010 IFGF cost of debt indicator $(0-100)$ & 79,71 & 78,80 & & 78,14 & $*$ & 80,52 & & 81,80 & * \\
\hline $\begin{array}{l}\text { Average } 2006-2010 \text { y-to-y change in IFGF cost of debt } \\
\text { indicator }(0-100)\end{array}$ & 0,15 & 0,07 & & 0,79 & $*$ & $-0,31$ & $*$ & $-0,07$ & \\
\hline \multicolumn{10}{|l|}{ Influence on HD: Demand for HD } \\
\hline $2000 \%$ of 6-17 year-old population & 26,53 & 26,80 & $*$ & 26,29 & $*$ & 26,68 & & 26,37 & \\
\hline $2000-2010$ change in $\%$ of $6-17$ year-old population & $-5,65$ & $-5,57$ & & $-5,59$ & & $-5,73$ & & $-5,73$ & \\
\hline $2000 \%$ of population living in urban areas & 58,27 & 54,66 & $*$ & 57,90 & & 59,90 & & 61,21 & * \\
\hline $\begin{array}{l}2000-2010 \text { change in } \% \text { of population living in urban ar- } \\
\text { eas }\end{array}$ & 4,82 & 5,14 & & 4,56 & & 5,01 & & 4,57 & \\
\hline 2000 Population: From 20,001 to 50,000 & 0,19 & 0,19 & & 0,21 & & 0,19 & & 0,17 & \\
\hline 2000 Population: From 50,001 to 100,000 & 0,05 & 0,04 & $*$ & 0,04 & $*$ & 0,07 & * & 0,07 & \\
\hline 2000 Population: $100,001+$ & 0,03 & 0,00 & $*$ & 0,01 & $*$ & 0,04 & & 0,08 & $*$ \\
\hline $2000-2010 \%$ change in total population & 10,19 & 9,30 & & 8,30 & $*$ & 12,00 & $*$ & 11,66 & * \\
\hline \multicolumn{10}{|l|}{ Influence on HD: Initial HD level } \\
\hline 2000 Income MHDI quartile: Lowest & 0,24 & 0,27 & $*$ & 0,19 & $*$ & 0,27 & & 0,23 & \\
\hline 2000 Income MHDI & 0,57 & 0,56 & $*$ & 0,58 & & 0,58 & & 0,59 & $*$ \\
\hline 2000 Longevity MHDI quartile: Lowest & 0,28 & 0,27 & & 0,33 & $*$ & 0,21 & $*$ & 0,31 & \\
\hline 2000 Longevity MHDI & 0,71 & 0,71 & & 0,71 & $*$ & 0,72 & * & 0,71 & \\
\hline 2000 Schooling MHDI quartile: Lowest & 0,29 & 0,33 & $*$ & 0,25 & $*$ & 0,32 & & 0,27 & \\
\hline 2000 Schooling MHDI & 0,33 & 0,31 & $*$ & 0,33 & & 0,33 & & 0,35 & $*$ \\
\hline Observations & 2.345 & 622 & & 642 & & 539 & & 542 & \\
\hline
\end{tabular}

Source: The author, based on raw data from Atlas do Desenvolvimento Humano no Brasil; Finbra - Finanças do Brasil; Sistema Firjan; Matriz de Informação Social.

Notes: $(0-100)=$ In a 0 to 100 scale. * Statistically different from the remainder of the working sample's mean at $\alpha=0.05$, according to the unequal variance $t$ test of means. ${ }^{* *}$ Considering the whole set of municipalities for which information is available $(n=5,563)$, average 2002-2010 per cent federal and state discretionary transfers are 2.70 and 1.84 , respectively.

2000 and 2010, on average. Initial Schooling MHDI levels in 2000 were less than half those of the longevity dimensions.

\section{Regression results}

Index), calculated by the Brazilian census bureau; reference date: August 1, 2010.
Estimations from the multinomial logit model are shown in Table 3. Specifications (1a) to (3a) concern Equation II and include dummies for states. Wald tests for the null hypothesis that all the coefficients associated with a given variable are jointly zero are presented in the rightmost column for $\alpha=0.05$. Specifications (1b) to (3b), shown in Appendix Table 1, replace the set of state dummies with random intercepts for states; results are similar across the two configurations.

Each ten-real raise in 2000 per capita income associated with a 3.1 per cent higher RRR for the double social gain group. Each one per cent point increase in the share of children in households with no middle school graduates seems to decrease double social gain RRR by 12.8 per cent. Only five municipalities (three in Minas Gerais and two in Mato Grosso) increased this indicator during the 2000s.

Almost all of the parameters regarding local budgets are not statistically significant. Out of ten covariates in each of the three estimations (1a to $3 a$ ), three 
Table 3 - Relative risk ratio estimates for the multinomial logit model with group affiliation as the dependent variable and dummies for states

\begin{tabular}{|c|c|c|c|c|}
\hline Variable & $\begin{array}{c}\text { (1a) } \\
\text { Longevity } \\
\text { gain, schooling } \\
\text { loss } \\
\text { (group 2) }\end{array}$ & $\begin{array}{c}\text { (2a) } \\
\text { Longevity } \\
\text { loss, schooling } \\
\text { gain } \\
\text { (group 3) }\end{array}$ & $\begin{array}{l}\text { (3a) } \\
\begin{array}{l}\text { Double social } \\
\text { gain }\end{array}\end{array}$ & $\begin{array}{l}\text { Wald test at } \alpha= \\
0.05 \text { Rejects Ho: } \\
\text { All } \beta \text { s }=0 \text { ? }\end{array}$ \\
\hline \multicolumn{5}{|l|}{ Influence on HD: Families } \\
\hline \multirow[t]{2}{*}{2000 Per capita income (in BRL 10s) } & 0.999 & $1.040 * * *$ & $1.031 * *$ & Yes \\
\hline & $(0.012)$ & $(0.014)$ & $(0.013)$ & \\
\hline \multirow[t]{2}{*}{$2000-2010 \%$ change in per capita income } & 0.993 & 1.005 & 1.007 & \\
\hline & $(0.005)$ & $(0.006)$ & $(0.006)$ & \\
\hline \multirow[t]{2}{*}{2000 Gini $(0-100)$} & 1.017 & $0.968 *$ & 1.020 & Yes \\
\hline & $(0.017)$ & $(0.019)$ & $(0.020)$ & \\
\hline \multirow[t]{2}{*}{ 2000-2010 change in Gini (0 - 100) } & 1.013 & 0.978 & 1.016 & \\
\hline & $(0.017)$ & $(0.020)$ & $(0.021)$ & \\
\hline \multirow{2}{*}{$\begin{array}{l}2000 \% \text { of children in households with no } \\
\text { middle school graduates }\end{array}$} & 0.983 & $0.905 * * *$ & $0.872 * * *$ & Yes \\
\hline & $(0.011)$ & $(0.013)$ & $(0.012)$ & \\
\hline \multirow{2}{*}{$\begin{array}{l}2000-2010 \text { change in } \% \text { of children in house- } \\
\text { holds with no middle school graduates }\end{array}$} & $0.974 * *$ & $0.792 * * *$ & $0.773 * * *$ & Yes \\
\hline & $(0.011)$ & $(0.013)$ & $(0.012)$ & \\
\hline \multicolumn{5}{|l|}{ Influence on HD: Governments } \\
\hline \multirow[t]{2}{*}{2000 per capital total revenues (in BRL 10s) } & $0.997 * *$ & 1.000 & 1.000 & Yes \\
\hline & $(0.001)$ & $(0.000)$ & $(0.000)$ & \\
\hline \multirow{2}{*}{$\begin{array}{l}\text { Average } 2000-2010 \text { y-to-y } \% \text { change in per } \\
\text { capita total revenues }\end{array}$} & 1.003 & 1.007 & 1.011 & \\
\hline & $(0.018)$ & $(0.018)$ & $(0.018)$ & \\
\hline \multirow{2}{*}{$\begin{array}{l}\text { Average } 2000-2010 \% \text { of municipality own } \\
\text { collection revenues }\end{array}$} & 1.005 & 0.987 & 0.978 & \\
\hline & $(0.014)$ & $(0.016)$ & $(0.016)$ & \\
\hline \multirow{2}{*}{$\begin{array}{l}\text { Average } 2000-2010 \text { y-to-y change in } \% \text { of } \\
\text { municipality own collection revenues }\end{array}$} & 1.027 & 1.033 & 1.011 & \\
\hline & $(0.082)$ & $(0.093)$ & $(0.090)$ & \\
\hline \multirow{2}{*}{$\begin{array}{l}\text { Average } 2002-2010 \% \text { of federal }+ \text { state dis- } \\
\text { cretionary transfers }\end{array}$} & $1.063 * *$ & 1.014 & 1.006 & \\
\hline & $(0.026)$ & $(0.028)$ & $(0.028)$ & \\
\hline \multirow{2}{*}{$\begin{array}{l}\text { Average } 2002-2010 \text { y-to-y change in } \% \text { of } \\
\text { federal + state discretionary transfers }\end{array}$} & 1.033 & 1.021 & 1.064 & \\
\hline & $(0.056)$ & $(0.066)$ & $(0.067)$ & \\
\hline \multirow{2}{*}{$\begin{array}{l}\text { Average } 2000-2010 \% \text { of total expenditures } \\
\text { spent in education and culture }\end{array}$} & 0.990 & 1.005 & 1.010 & \\
\hline & $(0.015)$ & $(0.019)$ & $(0.019)$ & \\
\hline \multirow{2}{*}{$\begin{array}{l}\text { Average } 2000-2010 \text { y-to-y change in } \% \text { of to- } \\
\text { tal expenditures spent in education and cul- } \\
\text { ture }\end{array}$} & $1.129^{*}$ & 1.090 & $1.248 * *$ & \\
\hline & $(0.081)$ & $(0.092)$ & $(0.112)$ & \\
\hline
\end{tabular}




\begin{tabular}{|c|c|c|c|c|}
\hline Variable & $\begin{array}{c}\text { (1a) } \\
\text { Longevity } \\
\text { gain, schooling } \\
\text { loss } \\
\text { (group 2) }\end{array}$ & $\begin{array}{c}(2 a) \\
\text { Longevity } \\
\text { loss, schooling } \\
\text { gain } \\
\text { (group 3) }\end{array}$ & $\begin{array}{c}\text { (3a) } \\
\begin{array}{l}\text { Double social } \\
\text { gain }\end{array} \\
\text { (group 4) }\end{array}$ & $\begin{array}{c}\text { Wald test at } \alpha= \\
0.05 \text { Rejects Ho: } \\
\text { All } \beta \mathrm{s}=0 ?\end{array}$ \\
\hline \multirow{2}{*}{$\begin{array}{l}\text { Average } 2000-2010 \% \text { of total expenditures } \\
\text { spent in health and sanitation }\end{array}$} & 0.999 & 0.990 & 1.000 & \\
\hline & $(0.017)$ & $(0.020)$ & $(0.020)$ & \\
\hline \multirow{2}{*}{$\begin{array}{l}\text { Average } 2000-2010 \text { y-to-y change in } \% \text { of to- } \\
\text { tal expenditures spent in health and sanitation }\end{array}$} & 1.091 & 1.086 & 1.122 & \\
\hline & $(0.086)$ & $(0.102)$ & $(0.107)$ & \\
\hline \multirow{2}{*}{$\begin{array}{l}\text { Average 2004-2010\% Programa Bolsa Fa- } \\
\text { milia coverage }\end{array}$} & 1.005 & 0.992 & 0.996 & \\
\hline & $(0.005)$ & $(0.006)$ & $(0.006)$ & \\
\hline \multirow{2}{*}{$\begin{array}{l}\text { Average } 2004-2010 \text { y-to-y change in } \% \\
\text { Programa Bolsa Familia coverage }\end{array}$} & 0.986 & $0.970^{*}$ & $0.965^{* *}$ & \\
\hline & $(0.014)$ & $(0.017)$ & $(0.017)$ & \\
\hline \multirow{2}{*}{$\begin{array}{l}\text { Average 2007-2010 Programa Bolsa Familia } \\
\text { IGD }(0 \text { - 100) }\end{array}$} & 0.991 & 1.015 & 1.007 & \\
\hline & $(0.010)$ & $(0.013)$ & $(0.012)$ & \\
\hline \multirow{2}{*}{$\begin{array}{l}\text { Average } 2007-2010 \text { y-to-y change in } \\
\text { Programa Bolsa Familia IGD }(0-100)\end{array}$} & 0.999 & 0.987 & 0.998 & \\
\hline & $(0.016)$ & $(0.019)$ & $(0.020)$ & \\
\hline \multirow[t]{2}{*}{ Average 2006-2010 IFGF (0 - 100) } & 1.008 & $1.020^{* *}$ & $1.017 *$ & \\
\hline & $(0.007)$ & $(0.009)$ & $(0.009)$ & \\
\hline \multirow{2}{*}{$\begin{array}{l}\text { Average } 2006-2010 \text { y-to-y change in IFGF (0 } \\
\text { - 100) }\end{array}$} & 1.012 & 0.994 & 0.986 & \\
\hline & $(0.016)$ & $(0.018)$ & $(0.020)$ & \\
\hline \multicolumn{5}{|l|}{ Influence on HD: Demand for $H D$} \\
\hline \multirow[t]{2}{*}{$2000 \%$ of 6-17 y-o population } & 1.007 & $1.132 * *$ & 1.086 & \\
\hline & $(0.045)$ & $(0.062)$ & $(0.058)$ & \\
\hline \multirow{2}{*}{$\begin{array}{l}2000-2010 \text { change in } \% \text { of } 6-17 \text { y-o popula- } \\
\text { tion }\end{array}$} & 1.002 & $1.116^{*}$ & 1.064 & \\
\hline & $(0.054)$ & $(0.065)$ & $(0.063)$ & \\
\hline \multirow[t]{2}{*}{$2000 \%$ of population living in urban areas } & 0.999 & 0.994 & $0.989 * *$ & \\
\hline & $(0.004)$ & $(0.005)$ & $(0.005)$ & \\
\hline \multirow{2}{*}{$\begin{array}{l}2000-2010 \text { change in } \% \text { of population living } \\
\text { in urban areas }\end{array}$} & 0.993 & 0.992 & 0.995 & \\
\hline & $(0.011)$ & $(0.012)$ & $(0.012)$ & \\
\hline \multirow[t]{2}{*}{2000 Population: From 20,001 to 50,000 } & $1.433 *$ & 1.012 & 1.378 & \\
\hline & $(0.268)$ & $(0.213)$ & $(0.298)$ & \\
\hline \multirow[t]{2}{*}{2000 Population: From 50,001 to 100,000} & 1.404 & 1.779 & $2.518^{* *}$ & \\
\hline & $(0.516)$ & $(0.634)$ & $(0.911)$ & \\
\hline \multirow[t]{2}{*}{2000 Population: 100,001+ } & 2.267 & $6.258^{* *}$ & $15.545 * * *$ & Yes \\
\hline & $(1.806)$ & $(4.562)$ & $(11.115)$ & \\
\hline \multirow[t]{2}{*}{$2000-2010 \%$ change in total population } & 1.004 & $0.989 * *$ & 0.996 & Yes \\
\hline & $(0.005)$ & $(0.005)$ & $(0.005)$ & \\
\hline
\end{tabular}




\begin{tabular}{|c|c|c|c|c|}
\hline Variable & $\begin{array}{c}\text { (1a) } \\
\text { Longevity } \\
\text { gain, schooling } \\
\text { loss } \\
\text { (group 2) }\end{array}$ & $\begin{array}{c}\text { (2a) } \\
\text { Longevity } \\
\text { loss, schooling } \\
\text { gain } \\
\text { (group 3) }\end{array}$ & $\begin{array}{c}\text { (3a) } \\
\begin{array}{l}\text { Double social } \\
\text { gain }\end{array} \\
\text { (group 4) }\end{array}$ & $\begin{array}{c}\text { Wald test at } \alpha= \\
0.05 \text { Rejects Ho: } \\
\text { All } \beta s=0 ?\end{array}$ \\
\hline \multicolumn{5}{|l|}{ Influence on HD: Initial HD level } \\
\hline 2000 Longevity MHDI quartile: Lowest & $\begin{array}{c}4.628 * * * \\
(1.058)\end{array}$ & $\begin{array}{c}0.979 \\
(0.241)\end{array}$ & $\begin{array}{c}4.016^{* * *} \\
(1.056)\end{array}$ & Yes \\
\hline 2000 Schooling MHDI quartile: Lowest & $\begin{array}{c}0.785 \\
(0.168)\end{array}$ & $\begin{array}{c}3.387 * * * \\
(0.876)\end{array}$ & $\begin{array}{c}2.877 * * * \\
(0.751)\end{array}$ & Yes \\
\hline Constant & $\begin{array}{c}0.229 \\
(0.476)\end{array}$ & $\begin{array}{c}0.088 \\
(0.208)\end{array}$ & $\begin{array}{c}0.022 \\
(0.054)\end{array}$ & N.a. \\
\hline Observations & 2,345 & 2,345 & 2,345 & N.a. \\
\hline
\end{tabular}

Notes: Calculated with robust standard errors. Mean Variance Inflation Factor $(\mathrm{VIF})=2.10$; maximum VIF $=7.92$. Pseudo- $\mathrm{R}^{2}$ for specifications (1a) to (3a) is 0.245. $(0-100)=$ In a 0 to 100 scale. N.a. $=$ Not applicable. $* * * p<0.01, * * p<0.05, * p<0.10$. Source: The author, based on raw data from Atlas do Desenvolvimento Humano no Brasil; Finbra - Finanças do Brasil; Sistema Firjan; Matriz de Informação Social.

20 These transfers do not include SUS transfers.

${ }^{21}$ During Brazil's boom years (for most of the 2000s), municipalities in a stalled economy may be the most poorly administered. In these areas, federal programs implemented at the local level, such as PBF, may also suffer show significance, and none is significant at $\alpha=0.05$ in more than one group comparison. Per capita total revenues appear to have a slightly negative association with the chances of falling into the longevity gain, schooling loss category relative to double social loss $(0.003$ reduction in the RRR for each $\mathrm{R} \$ 10$, ceteris paribus). This suggests that local budgetary resources in general - regardless of their sources and apportionment - cannot veer municipalities away from a double social loss, all else constant.

Per cent of federal plus state discretionary transfers ${ }^{20}$ positively correlates with escaping double social loss: one per cent point increase in discretionary transfers is estimated to raise in 6.3 per cent the risk ratio of falling into the longevity gain, schooling loss category. Since per capita revenues are held constant, this finding underscores the importance of intergovernmental transfers in compounding local budgets.

Specification (3a) detected a statistically significant connection between expenditures and group membership, but only via growth in the education and culture share of expenditures. This association was calculated to be in the neighbourhood of a 25 per cent increase in the double social gain RRR for each one per cent point increase in average year-to-year change, all else constant - which is a variation well above this explanatory variable's mean, of negative 0.24 (Table 2). Random intercepts specifications return only marginally significant associations for this covariate (Appendix Table 1).

The spreading pace of PBF shows a statistically significant coefficient, suggesting that as this program advanced towards full reach of the target group, the higher became the chance of falling into a double social loss. This may be the result of successful attempts to reach the most vulnerable persons, who may concentrate in municipalities that were least able to escape social losses. ${ }^{21}$

A one-point improvement in IFGF associates with a 1.7 per cent increase in the RRR for group 4, ceteris paribus. Since own collection (one of IFGF's dimensions) is held constant, this result is net of the partial redundancy between these two variables - which display a 0.528 correlation coefficient ${ }^{22}$ - and regards mostly the other four IFGF components. 
from weak management, and that could be a potential explanation for the regression results about PBF.

${ }^{22} p$-value $=0.000 ; \mathrm{n}=2,345$ (the working sample).

${ }^{23}$ The sheer positive correlation between per cent urban and population size, of moderate magnitude $(0.294$, $p$-value $=0.000)$ in the working sample $(\mathrm{n}=2,345)$, would not be expected to be pulling significance from urbanisation.
The younger the age profile, the more likely that a municipality will belong to group 3 (longevity loss, schooling gain) in relation to group 1 (double social loss), whereas urbanization seems to constrict chances of double social gain. ${ }^{23}$ Neither age profile nor urbanisation return statistically significant coefficients in the random intercepts specifications ( $1 \mathrm{~b}$ to $3 \mathrm{~b}$ ). Covariates concerning population size indicate that greater populaces are more likely to prevent double social loss and that such association is more intense the larger the population. Municipalities with over fifty thousand residents seem dramatically more likely to fall in groups 3 and 4, both of which imply schooling gains: RRRs are estimated to increase by a factor of two to fifteen, ceteris paribus. Population growth, nonetheless, returned a negative effect on the likelihood of pertaining to group 3, statistically significant in (2a) but not in (2b).

Aligned with the convergence pattern captured when groups were formed, initial schooling and longevity levels show a negative association with social gains. Being in the lowest 2000 longevity (schooling) quartile inflates by about three (two) times the probability of double social gains.

To check the results' sensitivity to the multinomial modelling, four logit regressions were estimated (Appendix Table 2). All have a dummy for double social gain as the dependent variable. Specifications (4a) and (4b) considered only the subsample of group 1 and group 4 municipalities, while (5a) and (5b) include the entire working sample. Specifications ending in "a" contain dummies for states, while those ending in "b" display random intercepts for states. In the four models, results are similar to those found through the multinomial analysis, with three exceptions. First, in (4a) own collection shows a negative and significant effect; second, in (4b) average 2000-2010 year-to-year change in private collection displays odds ratio around 1.2, and significant at $\alpha=0.05$. Possibly, such difference in results is due to subsampling, with only the "extreme" groups 1 and 4 present. The third difference is that discretionary transfers are not statistically significant in the logit models.

\section{Conclusion}

The research aimed at shedding light on the somewhat disjoint economic and social progress. To do that, examined municipalities making substantial strides towards improved longevity and schooling despite their dismal economic performance. Not the least, learning about characteristics shared by such localities is of interest to any shielding effort against downturns.

Leveraging causal claims on HD from a broad range of literature, I argue that public policy from central and local governments can have substantive effects on HD, net of variations on families' income. From this standpoint, public spending schedules could promote HD advancements amidst an unfavourable economy. I adapt the causal claims, from their original cross-country perspective to the institutional setting of Brazilian municipalities.

The preceding analysis suggests that, in a stalled or slow economy, the probability of social improvement is sensitive to families' income level, educational achievement in households with children, local budget composition and apportionment, age and size of the population, and already existing HD levels. Noteworthy, urbanisation did not seem to associate with advances in the social HD dimensions, all else constant.

Evidence gathered supports the proposed argument. Zooming in on governments' influence over the chances to escape double social loss, budgetary sources and spending appear to be more critical than sheer budget: ceteris paribus, models fail to capture a positive impact of the per capita total budget. Discretionary transfers, while not explicitly designed to be redistributive, may work to that end and seem to help avoid double social loss in lagging local econ- 
omies. Moreover, growing education spending shows a positive association with double social gain. Fiscal health, as captured by IFGF, too correlates with a drop in the likelihood of social loss.

Together, findings regarding the impact of education expenditures and the lingering effects of low schooling (captured by the per cent of children in households without middle school graduates) tell a story of intergenerational transmission of HD, and the role of the State in breaking the vicious cycle of handed down inequality. The fact that growth in education spending seems to help HD, while total revenue per se does not sport the same effect, suggests that policy priorities matter, beyond investment capacity.

Admittedly, several questions remain unanswered. Given the option to focus on municipalities with less than expected EG, this research does not inform on how HD behaves in thriving locales, nor on those that grew within the expected bounds. Also, I have not addressed the dynamic relationship between EG and HD - which could have implications as far as the sequencing of policy (e.g., invest in HD first or raise income first).

Moreover, this study does not deal with the reasons why certain municipalities receive more discretionary inflows or invest more in education than others, nor does it dissects the application of such funds. While decentralised public health care is highly regulated, with municipalities having to adhere to service provision protocols to secure SUS resources, how local governments spend in education is a far less constrained decision, giving up to greater variation in services offered across the country. With a positive predicted effect on HD, the fiscal health indicator (IFGF) too underscores the existence of room for local decisions (e.g., regarding investment and indebtedness) that seem to matter to HD. A possible account sheds light on covariates' initial levels. In 2000, Schooling MHDI averages were half that of Longevity MHDI; assuming diminishing returns of resources spent, money assigned to education would naturally yield higher a return. As far as fiscal health, initial IFGF components tended to be greater in the double social gain municipalities, and that advantageous legacy could be part of the explanation for their relative success in the subsequent decade.

Despite the relevance of angles not explored here, this article contributes to the literature in a variety of ways. First, it poses a practical question, which should interest academics and practitioners alike. Second, it articulates different fields of study, combining references from Development Studies, Political Science, and Education to elaborate an encompassing model for local HD. Third, besides the observational nature of the research design, the findings bear credibility as the analyses incorporate numerous controls and take advantage of longitudinal data wherever possible, holding constant a great many influences over HD.

Having established the boundaries and contributions of the study, its conclusion can be better understood. Piecing together the evidence amassed, escaping double social loss seems to hinge upon a variety of actors of differing spheres, looking more likely the higher the initial income and schooling levels, the greater the discretionary federal and state-level inflow, the growth in local education investments, and the fiscal health. A more balanced countrywide distribution of family and government resources foreshadows lesser vulnerability through rainy days.

Ana Paula Karruz (apkarruz@gmail.com) é Doutora em Políticas Públicas e Administração Pública pela George Washington University e Professora do Departamento de Ciência Política da Universidade Federal de Minas Gerais (UFMG). Coordena o Grupo Interdisciplinar de Metodologias em Avaliação de Políticas Públicas - GIMAPP/UFMG. Vínculo Institucional: Departamento de Ciência Política, UFMG, Belo Horizonte, MG, Brasil. 


\section{References}

Amaral, L.F.L.E., 2011. Os determinantes dos gastos educacionais e seus impactos sobre a qualidade do ensino. Dissertação de Mestrado. São Paulo: Universidade de São Paulo.

Amaral, L.F.L.E. \& Menezes-Filho, N.A., 2008. A relação entre gastos educacionais e desempenho escolar. In XXXVI Encontro Nacional de Economia (Anpec). Salvador.

Arretche, M.T.S., 2002. Relações federativas nas políticas sociais. Educação \& Sociedade, 23(80), pp.25-48. DOI: 8.1590/S0101-73302002008000003

Arretche, M.T.S., 2012. Democracia, federalismo e centralização no Brasil. Rio de Janeiro: FIOCRUZ/FGV.

Baldacci, E.; Clements, B.; Gupta, S. \& Cui, Q., 2008. Social Spending, Human Capital, and Growth in Developing Countries. World Development, 36(8), pp.1317-1341. DOI: 10.1016/j.worlddev.2007.08.003

Barseghyan, L. \& Dicecio, R., 2011. Cross-Country Income Convergence Revisited. Economic Letters, 113(3), pp.244-247. DOI: $10.20955 / w p .2010 .021$

Bertholini, F.; Pereira, C. \& Rennó, L., 2018. Pork is Policy: Dissipative Inclusion at the Local Level. Governance, 31(4), pp.701-720. DOI: 10.1111/gove.12331

Brollo, F. \& Nannicini, T., 2012. Tying Your Enemy's Hands in Close Races: The Politics of Federal Transfers in Brazil. American Political Science Review, 106(4), pp.742-761. DOI: 10.1017/S0003055412000433

Brunello, G.; Fort, M.; Schneeweis, N. \& Winter-Ebmer, R., 2011. The Causal Effect of Education on Health: What Is the Role of Health Behaviors? Available in http://ftp.iza.org/dp5944.pdf. Accessed Sep. 3, 2015.

Bueno, N.S., 2017. Bypassing the Enemy: Distributive Politics, Credit Claiming, and Nonstate Organizations in Brazil. Comparative Political Studies, 51(3), pp.304-340. DOI: 10.1177/0010414017710255

Ceneviva, R., 2012. O nível de governo importa para a qualidade da política pública? A municipalização da educação fundamental no Brasil. In $8^{\circ}$ Encontro da ABCP. Gramado.

Coelho, R.L.P. \& Figueiredo, L., 2007. Uma análise da hipótese de convergência para os municípios brasileiros. Revista Brasileira de Economia, 61(3), pp.331-352. DOI: 10.1590/S0034-71402007000300003

Costa, R.F.R. \& Castelar, L.I.M., 2015. O impacto das transferências constitucionais sobre os gastos dos municípios brasileiros. Análise Econômica, 33(64), pp.171-189. DOI: 10.22456/2176-5456.51004

Cutler, D.M.; Deaton, A. \& Lleras-Muney, A., 2006. The Determinants of Mortality. The Journal of Economic Perspectives, 20(3), pp.97-120. DOI: 10.1257/jep.20.3.97

Cutler, D.M. \& Lleras-Muney A., 2006. Education and Health: Evaluating Theories and Evidence. NBER Working Paper $n$. 12352. Available in http://www.nber.org/papers/w12352. Accessed Sep. 3, 2015. DOI: 10.3386/w12352

Dhongde, S. \& Miao, X., 2013. Cross-Country Convergence in Income Inequality. ECINEQ WP 2013-290. Available in http://www.ecineq.org/milano/WP/ECINEQ2013-290.pdf. Accessed Mar 3, 2016.

Diaz, M.D.M., 2012. Qualidade do gasto público municipal em ensino fundamental no Brasil. Economia Política, 32(1), pp.128-141. DOI: 10.1590/S0101-31572012000100008

Dixon, R.J. \& Thirlwall. A.P., 1975. A Model of Regional Growth-Rate Differences on Kaldorian Lines. Oxford Economic Papers, 27(2), pp.201-214. DOI: 10.1093/oxfordjournals.oep.a041312

Dollery, B. \& Worthington, A., 1995. Federal Expenditure and Fiscal Illusion: A Test of the Flypaper Hypothesis in Australia. Publius: The Journal of Federalism, 25(1), pp.23-34. DOI: 10.1093/oxfordjournals.pubjof.a038178

Domingos, L.C.; Silva, A.C.A. \& Souza, W.P.S.F., 2013. Impacto dos gastos educacionais no desempenho escolar: uma análise para a Paraíba no ano de 2011. In II Enpecon - Encontro Pernambucano de Economia: Crescimento, Bem-Estar e Sustentabilidade. Recife.

Evans, P. \& Heller, P., 2015. Human Development, State Transformation and the Politics of the Developmental State. In S. Leibfried; E. Huber; M. Lange; J.D. Levy; F. Nullmeier \& J.D. Stephens, eds. The Oxford Handbook of Transformations of the State. Oxford: Oxford University Press.

Faveret, A.C.S.C., 2003. A vinculação constitucional de recursos para a saúde: avanços, entraves e perspectivas. Ciência e Saúde Coletiva, 8(2), pp.371-378. DOI: 10.1590/S1413-81232003000200004

Fay, M. \& Opal, C., 1999. Urbanization Without Growth: A Not-So-Uncommon Phenomenon. World Bank Group Policy Research Working Papers. DOI: 10.1596/1813-9450-2412 Available in http://elibrary.worldbank.org/doi/abs/10.1596/1813-9450-2412. Accessed Jan. 1, 2016.

Feinstein, L.; Sabates R.; Anderson T. M.; Sorhaindo A. \& Hammond, C., 2006. The Effects of Education on Health: Concepts, Evidence and Policy Implications: A Review for the OECD Centre for Educational Research and Innovation (CERI). In OECD/CERI Symposium: Measuring the Social Outcomes of Learning (SOL). Copenhagen.

Ferreira, R.T. \& Cruz, M.S., 2008. Clubes de convergência na desigualdade de renda nos municípios brasileiros. In XXXVI Encontro Nacional de Economia (Anpec). Salvador.

Galeano, E.A.V., 2014. Evidências de desigualdades econômicas e convergência no PIB per capita entre os estados brasileiros no período de 1985 a 2008. Revista Econômica do Nordeste, 45(1), pp.19-33. DOI: 10.5380/re.v41i1.37052

Gonçalves, F.O. \& França, M.T.A., 2010. Políticas públicas, desenvolvimento regional e diferenciais de qualidade educacional nos municípios nordestinos. Series Working Paper BNDES/ANPEC. Available in http://www.bndes.gov.br/SiteBNDES/export/sites/default/bndes_pt/Galerias/Arquivos/produtos/down-

load/pde/PDE2009_UFPR_Goncalves_Franca.pdf. Accessed Feb. 2, 2016. 
Gupta, S.; Verhoeven, M. \& Tiongson, E.R., 2002. The Effectiveness of Government Spending on Education and Health Care in Developing and Transition Economies. European Journal of Political Economy, 18(4), pp.717-737. DOI: 10.1016/S0176-2680(02)00116-7

Ingraham, P.W., 2007. Studying State and Local Management Systems: Why We Need to Do It. In Ingraham, P.W., ed. In Pursuit of Performance: Management Systems in State and Local Government. Baltimore: The John Hopkins University Press.

Ingraham, P.W.; Joyce, P.G. \& Donahue, A.K., 2003. Government Performance: Why Management Matters. Baltimore: The John Hopkins University Press.

Jannuzzi, P.M. \& Pinto, A.R., 2013. Bolsa Família e seus impactos nas condições de vida da população brasileira: uma síntese dos principais achados da Pesquisa de Avaliação de Impacto do Bolsa Família II. In T. Campello \& M.C. Neri, eds. Programa Bolsa Família: uma década de inclusão e cidadania. Brasília: Instituto de Pesquisa Econômica Aplicada (IPEA).

Jordá, V. \& Sarabia, J.M., 2015a. International Convergence in Well-Being Indicators. Social Indicators Research, 120(1), pp.1-27. DOI: 10.1007/s11205-014-0588-8

Jordá, V. \& Sarabia, J.M, 2015b. Well-Being Distribution in the Globalization Era: 30 Years of Convergence. Applied Research in Quality of Life, 10(1), pp.123-140. DOI: 10.1007/s11482-014-9304-8

Kaldor, N., 1978. Further Essays on Economic Theory. New York: Holmes and Meier Pub.

Karruz, A.P. \& Vale, M.L.F.R., 2015. How Has Brazilian Municipalities' Human Development Index Been Raised? A growth decomposition and local expenditures analysis. In Midwest Political Science Association Annual $73^{\text {rd }}$ Conference. Chicago.

Kenny, C., 2005. Why Are We Worried about Income? Nearly Everything that Matters is Converging. World Development, 33(1), pp.1-19. DOI: 10.1016/j.worlddev.2004.06.016

Kenny, C., 2009. There's More to Life than Money: Exploring the Levels/Growth Paradox in Income and Health. Journal of International Development, 21(1), pp.24-41. DOI: 10.1002/jid.1499

Kónya, L., 2011. New Panel Data Evidence of Human Development Convergence from 1975 to 2005. Global Business and Economics Review, 13(1), pp.57-70. DOI: 10.1504/GBER.2011.039190

Kónya, L. \& Guisan, M.C., 2008. What Does the Human Development Index Tell us about Convergence? Applied Econometrics and International Development, 8(1), pp.19-40. DOI: 10.1111/j.1460-9568.2012.08171.x

Kroth, D.C. \& Gonçalves, F.O., 2014. Impactos dos gastos públicos municipais sobre a qualidade da educação: uma análise de variáveis instrumentais para o período 2007-2011. In XLII Encontro Nacional de Economia (Anpec). Natal.

Leme, M.C.; Paredes, R. \& Souza, A.P., 2009. A municipalização do ensino fundamental e seu impacto sobre a proficiência no Brasil. In F. Veloso; S. Pessôa \& F. Giambiagi, eds. Educação básica no Brasil: construindo o país do futuro. Rio de Janeiro: Campus-Elsevier.

Long, J.S. \& Freese, J., 2001. Regression Models For Categorical Dependent Variables Using Stata. College Station: Stata Press.

Marenco, A.; Strohschoen, M.T.B.; Joner, W., 2017. Capacidade estatal, burocracia e tributação nos municípios brasileiros. Revista de Sociologia e Política, 25(64), pp.3-21. DOI: 10.1590/1678-987317256401

Marques, A.M. \& Fochezatto, A., 2012. Desenvolvimento convergente ou divergente entre os estados brasileiros? Uma análise multidimensional, 1970-2000. In XV Encontro de Economia da Região Sul (Anpec-Sul). Porto Alegre.

Marshall, F.L.L., 1989. Fiscal Illusion in Public Finance: A Theoretical and Empirical Study. Tese de Doutorado. College Park: University of Maryland.

Mayer-Foulkes, D., 2010. Divergences and Convergences in Human Development. UNDP Research Paper, 2010-20. Available in http://hdr.undp.org/sites/default/files/hdrp_2010_20.pdf. Accessed Dec. 14, 2014.

Myrdal, G., 1968. Teoria econômica e regiões subdesenvolvidas. Rio de Janeiro: Saga.

Neumayer, E., 2003. Beyond Income: Convergence in Living Standards, Big Time. Structural Change and Economic Dynamics, 14(3), pp.275-296. DOI: 10.1016/S0954-349X(02)00047-4

Noorbakhsh, F., 2006. International Convergence or Higher Inequality of Human Development? Evidence for 1975 to 2002. ONU-WIDER Working Paper 2016-15. Available in https://www.wider.unu.edu/publication/international-convergence-or-higher-inequality-human-development. Accessed Jan. 1, 2017.

Nunes, F., 2015. Presidentialism, Decentralization, and Distributive Politics in Latin America. Tese de Doutorado. Los Angeles: University of California.

Oliveira, D.L., 2005. A “nova” saúde pública e a promoção da saúde via educação: entre a tradição e a inovação. Revista Latino-Americana de Enfermagem, 13(3), pp.423-431. DOI: 10.1590/S0104-11692005000300018

Paiva, L.H.; Soares, F.V.; Cireno, F.; Viana, I.A.V. \& Duran, A.C., 2016. The Effects of Conditionality Monitoring on Educational Outcomes: Evidence from Brazil's Bolsa Família Programme. Working Paper n. 144. International Policy Centre for Inclusive Growth. Available in http://www.ipc-undp.org/pub/eng/WP144_The_effects_of_conditionality_monitoring_on_educational_outcomes.pdf .Accessed July 1, 2016.

Ranis, G. \& Stewart, F., 2001. Growth and Human Development: Comparative Latin American Experience. The Developing Economies, 39(4), pp.333-365. DOI: 10.1111/j.1746-1049.2001.tb00902.x

Ranis, G.; Stewart, F. \& Ramirez, A., 2000. Economic Growth and Human Development. World Development, 28(2), pp.197-219. DOI: 10.1016/s0305-750x(99)00131-x 
Ribeiro, E.C.B.A. \& Almeida, E.S.O., 2012. Convergência local de renda no Brasil. Economia Aplicada, 16(3), pp.399-420. DOI: $10.1590 / \mathrm{S} 1413-80502012000300003$

Schultz, T. P., 2002. Why Governments Should Invest More to Educate Girls. World Development, 30(2), pp.207-225. DOI: 10.1016/s0305-750x(01)00107-3

Sen, A., 1999. Development as Freedom. New York: Oxford University Press.

Silveira Neto, R.M., 2010. Redução recente da desigualdade regional de renda no Brasil: desconcentração industrial ou políticas sociais? In XXXVIII Encontro Nacional de Economia (Anpec). Salvador.

Soares, S., 2012. Bolsa Família, Its Design, Its Impacts and Possibilities for the Future. Available in http://www.ipcundp.org/pub/IPCWorkingPaper89.pdf. Accessed Apr. 1, 2016.

Soares, J.F. \& Alves, M.T.G., 2013. Effects of Schools and Municipalities in the Quality of Basic Education. Cadernos de Pesquisa, 43(149), pp.492-517. DOI: 10.1590/S0100-15742013000200007

Soares, M.M. \& Melo, B.G., 2016. Condicionantes políticos e técnicos das transferências voluntárias da União aos municípios brasileiros. Revista de Administração Pública, 50(4), pp.539-561. DOI: 10.1590/0034-7612138727

Sollow, R.M., 1956. A Contribution to the Theory of Economic Growth. Quarterly Journal of Economics, 70(1), pp.65-94. DOI: $10.2307 / 1884513$

Souza, C., 2004. Governos locais e gestão de políticas sociais universais. São Paulo em Perspectiva, 18(2), pp.27-41. DOI: 10.1590/S0102-88392004000200004

Suri, T.; Boozer, M.A.; Ranis, G. \& Stewart, F., 2011. Paths To Success: The Relationship between Human Development and Economic Growth. World Development, 39(4), pp.506-522. DOI: 10.1016/j.worlddev.2010.08.020

Swan, T.W., 1956. Economic Growth and Capital Accumulation. Economic Record, 32(2), pp.334-361. DOI: 10.1111/j.14754932.1956.tb00434.x

Vazquez, D.A., 2014. Mecanismos institucionais de regulação federal e seus resultados nas políticas de educação e saúde. $D a$ dos, 57(4), pp.969-1005. DOI: 10.1590/00115258201430

Veloso, J.F.A.; Monasterio, L.M.; Vieira, R.S. \& Miranda, R.B., 2011. Uma visão inicial dos subsistemas da gestão pública municipal. In Veloso, J.F.A.; Monasterio, L.M.; Vieira, R.S. \& Miranda, R.B., eds. Gestão municipal no Brasil: um retrato das prefeituras. Brasília: IPEA. Available in http://ipea.gov.br/portal/index.php?option=com_content\&view=article\&id=10200. Accessed Jan. 9, 2018.

Weare, K., 2002. The Contribution of Education to Health Promotion. In Bunton, R. \& G. Macdonald, eds. Health promotion: disciplines, diversity and developments. London: Routledge.

\section{Other sources}

Atlas do Desenvolvimento Humano no Brasil. Available in http://atlasbrasil.org.br/2013/. Accessed Jan. 9, 2018.

Finbra - Finanças do Brasil. Available in http://www.tesouro.fazenda.gov.br/pt_PT/contas-anuais. Accessed Jan. 9, 2018.

INEP. Instituto de Estudos e Pesquisas Educacionais Anísio Teixeira, 2016. Sinopse estatística da educação básica 2015. Brasília: INEP. Available in http://inep.gov.br/sinopses-estatisticas-da-educacao-basica. Accessed April 2, 2018.

INEP. Instituto de Estudos e Pesquisas Educacionais Anísio Teixeira, 2017. Sinopse estatística da educação básica 2010. Brasília: INEP. Available in http://inep.gov.br/sinopses-estatisticas-da-educacao-basica. Accessed April 2, 2018.

Matriz de Informação Social. Available in http://mds.gov.br/assuntos/bolsa-familia/dados. Accessed Jan. 9, 2018.

MDS. Ministério do Desenvolvimento Social, 2018. Relatórios de informações sociais. Available in https://aplicacoes.mds.gov.br/sagi/RIv3/geral/index.php?relatorio=153\&file=entrada. Accessed Jan. 9, 2018.

PNUD. Programa das Nações Unidas para o Desenvolvimento; IPEA. Instituto de Pesquisa Econômica Aplicada \& FJP. Fundação João Pinheiro, 2013. O Índice de Desenvolvimento Humano Municipal brasileiro. Brasília: PNUD/IPEA/FJP.

Sistema Firjan, 2015. IFGF 2015 Firjan Fiscal Management Index. Available in http://www.firjan.com.br/data/files/A1/D2/28/1E/332BE410C4A41BE4F8A809C2/IFGF-English-Version.pdf. Accessed Apr. 4, 2016.

UNDP. United Nations Development Programme, 2015. 2015 Human Development Report - Rethinking Work for Human Development. Available inhttp://hdr.undp.org/en/2015-report/download. Accessed Apr. 4, 2016. 


\section{Em tempos difíceis: avançando educação e saúde a despeito de uma economia local desfavorável}

RESUMO Introdução: Embora os padrões de vida tenham melhorado substancialmente no Brasil, os últimos anos testemunharam uma economia com crescimento lento, levantando preocupações sobre se as melhorias em educação e saúde pública se consolidariam. São colocadas questões sobre como os governos de todo o país podem se proteger contra a turbulência econômica e continuar melhorando as condições sociais mesmo em períodos críticos. Especificamente, quais políticas públicas podem sustentar ou mesmo aumentar o desenvolvimento humano $(\mathrm{DH})$ na ausência de crescimento econômico (CE)? Materiais e Métodos: Este estudo explora as características sociodemográficas e orçamentárias dos municípios brasileiros que apresentaram crescimento menor do que o esperado na dimensão renda do Índice de Desenvolvimento Humano Municipal (IDH), mas avançaram mais que o esperado na escolaridade e expectativa de vida. Municípios cuja renda per capita média avançou menos do que o previsto foram agrupados de acordo com o crescimento das dimensões sociais do IDHM. As chances de cair em um determinado grupo foram estimadas através de um modelo logit multinomial. Resultados: A análise sugere que, em uma economia paralisada ou lenta, a probabilidade de melhoria social é sensível ao nível de renda das famílias, alcance educacional em famílias com crianças, composição e alocação do orçamento local, idade e tamanho da população e níveis de DH já existentes. Discussão: O artigo argumenta que influências não relacionadas à renda - ou seja, políticas públicas de governos centrais e locais - podem ter efeitos substanciais sobre o DH, contendo perdas ou mesmo promovendo avanços do DH em meio a uma economia desfavorável. Tal afirmação se baseia em trabalhos de estudos de desenvolvimento, adaptando-os da perspectiva comparativa entre países para o nível entre municípios. Além disso, pesquisas sobre descentralização e federalismo fiscal fornecem fundamentos para ajustar o modelo teórico. Uma distribuição nacional mais equilibrada de recursos familiares e governamentais antecipa menor vulnerabilidade em tempos críticos.

PALAVRAS-CHAVE: desenvolvimento humano, crescimento econômico, gasto social, município, Brasil.

This is an Open Access article distributed under the terms of the Creative Commons Attribution Non-Commercial License which permits unrestricted non-commercial use, distribution, and reproduction in any medium provided the original work is properly cited. 


\section{Appendix tables}

Table 1A - Relative risk ratio estimates for the multinomial logit model with group affiliation as the dependent variable and state random intercepts

\begin{tabular}{|c|c|c|c|}
\hline Variable & $\begin{array}{c}\text { (1b) } \\
\text { Longevity } \\
\text { gain, schooling loss } \\
\text { (group 2) }\end{array}$ & $\begin{array}{c}\text { (2b) } \\
\text { Longevity } \\
\text { loss, schooling gain } \\
\text { (group 3) }\end{array}$ & $\begin{array}{c}\text { (3b) } \\
\text { Double social gain } \\
\text { (group 4) }\end{array}$ \\
\hline Influence on HD: Families & & & \\
\hline 2000 Per capita income (in BRL 10s) & $\begin{array}{c}1.003 \\
(0.010)\end{array}$ & $\begin{array}{l}1.031 * * \\
(0.015)\end{array}$ & $\begin{array}{c}1.043 * * * \\
(0.014)\end{array}$ \\
\hline $2000-2010 \%$ change in per capita income & $\begin{array}{c}0.994 \\
(0.005)\end{array}$ & $\begin{array}{c}1.006 \\
(0.006)\end{array}$ & $\begin{array}{c}1.007 \\
(0.006)\end{array}$ \\
\hline 2000 Gini $(0-100)$ & $\begin{array}{c}1.005 \\
(0.023)\end{array}$ & $\begin{array}{l}0.987 \\
(0.022)\end{array}$ & $\begin{array}{c}1.013 \\
(0.032)\end{array}$ \\
\hline 2000-2010 change in Gini $(0-100)$ & $\begin{array}{c}1.000 \\
(0.017)\end{array}$ & $\begin{array}{c}0.994 \\
(0.024)\end{array}$ & $\begin{array}{c}1.013 \\
(0.031)\end{array}$ \\
\hline $\begin{array}{l}2000 \% \text { of children in households with no middle } \\
\text { school graduates }\end{array}$ & $\begin{array}{c}0.991 \\
(0.011)\end{array}$ & $(0.017)$ & $\begin{array}{c}0.876^{* * *} \\
(0.015)\end{array}$ \\
\hline $\begin{array}{l}2000-2010 \text { change in } \% \text { of children in households } \\
\text { with no middle school graduates }\end{array}$ & $\begin{array}{c}0.981 \\
(0.012)\end{array}$ & $(0.016)$ & $(0.009)$ \\
\hline $\begin{array}{l}\text { Influence on HD: Governments } \\
2000 \text { per capital total revenues (in BRL 10s) }\end{array}$ & $\begin{array}{c}0.996 * * * \\
(0.001)\end{array}$ & $\begin{array}{r}1.000 \\
(0.000)\end{array}$ & $\begin{array}{l}1.000 \\
(0.000)\end{array}$ \\
\hline $\begin{array}{l}\text { Average } 2000-2010 \text { y-to-y } \% \text { change in per capita to- } \\
\text { tal revenues }\end{array}$ & $\begin{array}{c}0.995 \\
(0.008)\end{array}$ & $\begin{array}{c}1.007 \\
(0.015)\end{array}$ & $\begin{array}{c}1.011 \\
(0.016)\end{array}$ \\
\hline $\begin{array}{l}\text { Average } 2000-2010 \% \text { of municipality own collection } \\
\text { revenues }\end{array}$ & $\begin{array}{c}1.013 \\
(0.018)\end{array}$ & $\begin{array}{c}0.982 \\
(0.015)\end{array}$ & $\begin{array}{c}0.973 \\
(0.017)\end{array}$ \\
\hline $\begin{array}{l}\text { Average } 2000-2010 \text { y-to-y change in } \% \text { of munici- } \\
\text { pality own collection revenues }\end{array}$ & $\begin{array}{c}1.026 \\
(0.061)\end{array}$ & $\begin{array}{c}1.057 \\
(0.058)\end{array}$ & $\begin{array}{c}1.049 \\
(0.063)\end{array}$ \\
\hline $\begin{array}{l}\text { Average } 2002-2010 \% \text { of federal + state discretionary } \\
\text { transfers }\end{array}$ & $\begin{array}{l}1.044 * * \\
(0.018)\end{array}$ & $\begin{array}{c}1.034 \\
(0.033)\end{array}$ & $\begin{array}{c}1.009 \\
(0.032)\end{array}$ \\
\hline $\begin{array}{l}\text { Average } 2002-2010 \text { y-to-y change in } \% \text { of federal }+ \\
\text { state discretionary transfers }\end{array}$ & $\begin{array}{c}1.024 \\
(0.057)\end{array}$ & $\begin{array}{c}1.061 \\
(0.070)\end{array}$ & $\begin{array}{c}1.069 \\
(0.070)\end{array}$ \\
\hline $\begin{array}{l}\text { Average } 2000-2010 \% \text { of total expenditures spent in } \\
\text { education and culture }\end{array}$ & $\begin{array}{c}0.972 \\
(0.017)\end{array}$ & $\begin{array}{c}1.038 \\
(0.024)\end{array}$ & $\begin{array}{c}1.004 \\
(0.022)\end{array}$ \\
\hline $\begin{array}{l}\text { Average } 2000-2010 \text { y-to-y change in } \% \text { of total ex- } \\
\text { penditures spent in education and culture }\end{array}$ & $\begin{array}{c}1.043 \\
(0.059)\end{array}$ & $\begin{array}{l}1.168 * \\
(0.109)\end{array}$ & $\begin{array}{l}1.186 * \\
(0.117)\end{array}$ \\
\hline
\end{tabular}



gain, schooling loss

Average $2000-2010 \%$ of total expenditures spent in health and sanitation

Average 2000-2010 y-to-y change in \% of total expenditures spent in health and sanitation

Average 2004-2010\% Programa Bolsa Familia coverage

Average 2004-2010 y-to-y change in \% Programa

Bolsa Familia coverage

Average 2007-2010 Programa Bolsa Familia IGD (0 - 100)

Average 2007-2010 y-to-y change in Programa Bolsa Familia IGD (0 - 100)

Average 2006-2010 IFGF (0 - 100)

Average 2006-2010 y-to-y change in IFGF (0 - 100)

Influence on HD: Demand for HD

$2000 \%$ of $6-17$ y-o population

2000-2010 change in \% of 6-17 y-o population

$2000 \%$ of population living in urban areas

2000-2010 change in \% of population living in urban areas

2000 Population: From 20001 to 50000

2000 Population: From 50001 to 100000

2000 Population: 100 001+

$2000-2010 \%$ change in total population

Influence on HD: Initial HD level

2000 Longevity MHDI quartile: Lowest (1b)

Longevity

(group 2)

(2b)

(3b)

\begin{tabular}{|c|c|c|}
\hline 0.987 & 1.012 & 1.014 \\
\hline$(0.019)$ & $(0.020)$ & $(0.023)$ \\
\hline $1.145^{*}$ & 0.975 & 1.075 \\
\hline$(0.087)$ & $(0.118)$ & $(0.091)$ \\
\hline 1.004 & 0.996 & 0.999 \\
\hline$(0.006)$ & $(0.008)$ & $(0.008)$ \\
\hline $0.974 * *$ & 0.986 & $0.970 * *$ \\
\hline$(0.011)$ & $(0.010)$ & $(0.015)$ \\
\hline 0.989 & 1.017 & 0.998 \\
\hline (0.009) & $(0.018)$ & $(0.016)$ \\
\hline 0.993 & 0.997 & 0.993 \\
\hline$(0.017)$ & $(0.029)$ & $(0.024)$ \\
\hline 1.008 & $1.020 * *$ & $1.024 * * *$ \\
\hline$(0.006)$ & $(0.009)$ & $(0.008)$ \\
\hline 1.017 & 0.987 & 0.987 \\
\hline$(0.014)$ & $(0.017)$ & $(0.016)$ \\
\hline 0.986 & 1.105 & 1.108 \\
\hline$(0.050)$ & $(0.079)$ & (0.093) \\
\hline 1.005 & 1.070 & 1.068 \\
\hline$(0.051)$ & $(0.074)$ & $(0.093)$ \\
\hline 0.998 & 0.998 & 0.990 \\
\hline$(0.006)$ & $(0.006)$ & $(0.007)$ \\
\hline 0.989 & 0.999 & 0.990 \\
\hline$(0.011)$ & $(0.009)$ & $(0.010)$ \\
\hline 1.272 & 1.214 & 1.161 \\
\hline$(0.241)$ & $(0.214)$ & $(0.252)$ \\
\hline 1.118 & $2.136 * * *$ & 1.961 \\
\hline$(0.650)$ & $(0.597)$ & $(0.898)$ \\
\hline 1.372 & $7.667 * * *$ & $10.739 * * *$ \\
\hline (1.480) & $(4.250)$ & (6.757) \\
\hline 0.999 & 0.994 & 0.994 \\
\hline$(0.003)$ & $(0.004)$ & $(0.004)$ \\
\hline $3.297 * * *$ & 1.110 & $4.614 * * *$ \\
\hline$(1.217)$ & $(0.303)$ & (1.165) \\
\hline
\end{tabular}

Longevity Double social gain loss, schooling gain

(group 3)

(group 4)

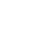

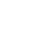


Variable

2000 Schooling MHDI quartile: Lowes

Constant

Observations (1b)

Longevity gain, schooling loss (2b)

Longevity loss, schooling gain

(group 2)

$0.725 * *$

(0.107)

6.596

(8.681)

2345 (group 3)

$4.383 * * *$

(1.430)

0.005

(0.016)

2345 (3b)

Double social gain

(group 4)

$3.050 * * *$

(0.749)

0.031

(0.093)

2345

Notes: Calculated with robust standard errors. $(0-100)=$ In a 0 to 100 scale. $* * * p<0.01, * * p<0.05, * p<0.10$.

Source: The author, based on raw data from Atlas do Desenvolvimento Humano no Brasil; Finbra - Finanças do Brasil; Sistema Firjan; Matriz de Informação Social. 
Table 2A - Odds ratio estimates for the logit models with affiliation to group 4 (double social gain) as the dependent variable

\begin{tabular}{|c|c|c|c|c|}
\hline \multirow[t]{2}{*}{ Variable } & (4a) & $(4 b)$ & (5a) & $(5 b)$ \\
\hline & $\begin{array}{c}\text { Double social } \\
\text { gain (vs. double } \\
\text { social loss) }\end{array}$ & $\begin{array}{c}\text { Double social } \\
\text { gain (vs. double } \\
\text { social loss) }\end{array}$ & $\begin{array}{c}\text { Double social } \\
\text { gain (vs. all } \\
\text { other groups) }\end{array}$ & $\begin{array}{c}\text { Double social } \\
\text { gain (vs. all } \\
\text { other groups) }\end{array}$ \\
\hline \multicolumn{5}{|l|}{ Influence on HD: Families } \\
\hline \multirow[t]{2}{*}{2000 Per capita income (in BRL 10s) } & 1.020 & 1.029 & 1.011 & $1.017 * *$ \\
\hline & $(0.015)$ & $(0.018)$ & $(0.009)$ & $(0.008)$ \\
\hline \multirow[t]{2}{*}{$2000-2010 \%$ change in per capita income } & 0.998 & 1.001 & 1.006 & $1.007 * *$ \\
\hline & $(0.007)$ & $(0.008)$ & $(0.005)$ & $(0.003)$ \\
\hline \multirow[t]{2}{*}{2000 Gini $(0$ - 100) } & 1.025 & 1.019 & $1.029 *$ & 1.024 \\
\hline & $(0.026)$ & $(0.042)$ & $(0.017)$ & $(0.021)$ \\
\hline \multirow[t]{2}{*}{ 2000-2010 change in Gini $(0$ - 100) } & 1.037 & 1.026 & 1.021 & 1.016 \\
\hline & $(0.028)$ & $(0.044)$ & $(0.017)$ & $(0.021)$ \\
\hline \multirow{2}{*}{$\begin{array}{l}2000 \% \text { of children in households with no middle } \\
\text { school graduates }\end{array}$} & $0.849 * * *$ & $0.854 * * *$ & $0.914 * * *$ & $0.917 * * *$ \\
\hline & $(0.016)$ & $(0.016)$ & $(0.010)$ & $(0.016)$ \\
\hline \multirow{2}{*}{$\begin{array}{l}2000-2010 \text { change in } \% \text { of children in households } \\
\text { with no middle school graduates }\end{array}$} & $0.745 * * *$ & $0.745 * * *$ & $0.865 * * *$ & $0.865 * * *$ \\
\hline & $(0.018)$ & $(0.013)$ & $(0.010)$ & $(0.017)$ \\
\hline \multicolumn{5}{|l|}{ Influence on HD: Governments } \\
\hline \multirow[t]{2}{*}{2000 per capital total revenues (in BRL 10s) } & 0.998 & 0.999 & $1.000 * * *$ & $1.000 * * *$ \\
\hline & $(0.002)$ & $(0.003)$ & $(0.000)$ & $(0.000)$ \\
\hline \multirow{2}{*}{$\begin{array}{l}\text { Average } 2000-2010 \text { y-to-y } \% \text { change in per capita } \\
\text { total revenues }\end{array}$} & 1.001 & 1.001 & 1.005 & 1.005 \\
\hline & $(0.007)$ & $(0.007)$ & $(0.005)$ & $(0.007)$ \\
\hline \multirow{2}{*}{$\begin{array}{l}\text { Average } 2000-2010 \% \text { of municipality own col- } \\
\text { lection revenues }\end{array}$} & $0.963 * *$ & $0.967 *$ & 0.987 & 0.986 \\
\hline & $(0.016)$ & $(0.020)$ & $(0.011)$ & $(0.010)$ \\
\hline \multirow{2}{*}{$\begin{array}{l}\text { Average } 2000-2010 \text { y-to-y change in } \% \text { of munic- } \\
\text { ipality own collection revenues }\end{array}$} & $1.233^{*}$ & $1.232 * *$ & 0.992 & 0.996 \\
\hline & $(0.149)$ & $(0.126)$ & $(0.068)$ & $(0.068)$ \\
\hline \multirow{2}{*}{$\begin{array}{l}\text { Average } 2002-2010 \% \text { of federal + state discre- } \\
\text { tionary transfers }\end{array}$} & 0.992 & 0.992 & 0.985 & 0.984 \\
\hline & $(0.033)$ & $(0.036)$ & $(0.021)$ & $(0.022)$ \\
\hline \multirow{2}{*}{$\begin{array}{l}\text { Average } 2002-2010 \text { y-to-y change in } \% \text { of federal } \\
+ \text { state discretionary transfers }\end{array}$} & 1.088 & 1.088 & 1.046 & 1.044 \\
\hline & $(0.097)$ & $(0.074)$ & $(0.050)$ & $(0.047)$ \\
\hline \multirow{2}{*}{$\begin{array}{l}\text { Average } 2000-2010 \% \text { of total expenditures spent } \\
\text { in education and culture }\end{array}$} & 1.015 & 1.009 & 1.010 & 1.005 \\
\hline & $(0.022)$ & $(0.029)$ & $(0.015)$ & $(0.016)$ \\
\hline \multirow{2}{*}{$\begin{array}{l}\text { Average } 2000-2010 \text { y-to-y change in } \% \text { of total } \\
\text { expenditures spent in education and culture }\end{array}$} & 1.178 & $1.148 *$ & $1.163 * *$ & $1.136^{* *}$ \\
\hline & $(0.117)$ & $(0.094)$ & $(0.087)$ & $(0.071)$ \\
\hline \multirow{2}{*}{$\begin{array}{l}\text { Average } 2000-2010 \% \text { of total expenditures spent } \\
\text { in health and sanitation }\end{array}$} & 1.007 & 1.011 & 1.006 & 1.006 \\
\hline & $(0.024)$ & $(0.022)$ & $(0.015)$ & $(0.016)$ \\
\hline \multirow{2}{*}{$\begin{array}{l}\text { Average } 2000-2010 \text { y-to-y change in } \% \text { of total } \\
\text { expenditures spent in health and sanitation }\end{array}$} & 1.074 & 1.068 & 1.040 & 1.040 \\
\hline & $(0.114)$ & $(0.102)$ & $(0.078)$ & $(0.060)$ \\
\hline
\end{tabular}




\begin{tabular}{|c|c|c|c|c|}
\hline \multirow{2}{*}{$\begin{array}{l}\text { Average 2004-2010\% Programa Bolsa Familia } \\
\text { coverage }\end{array}$} & 0.998 & 0.999 & 0.999 & 0.999 \\
\hline & $(0.007)$ & $(0.010)$ & $(0.005)$ & $(0.004)$ \\
\hline \multirow{2}{*}{$\begin{array}{l}\text { Average } 2004-2010 \text { y-to-y change in } \% \text { Programa } \\
\text { Bolsa Familia coverage }\end{array}$} & $0.954 * *$ & $0.958 * *$ & 0.981 & 0.980 \\
\hline & $(0.021)$ & $(0.021)$ & $(0.013)$ & $(0.013)$ \\
\hline \multirow{2}{*}{$\begin{array}{l}\text { Average } 2007-2010 \text { Programa Bolsa Familia IGD } \\
(0-100)\end{array}$} & 0.999 & 0.996 & 1.002 & 0.999 \\
\hline & $(0.014)$ & $(0.014)$ & $(0.010)$ & $(0.011)$ \\
\hline \multirow{2}{*}{$\begin{array}{l}\text { Average } 2007-2010 \text { y-to-y change in Programa } \\
\text { Bolsa Familia IGD }(0-100)\end{array}$} & 0.990 & 0.990 & 1.006 & 1.003 \\
\hline & $(0.025)$ & $(0.025)$ & $(0.016)$ & $(0.012)$ \\
\hline \multirow[t]{2}{*}{ Average 2006-2010 IFGF (0 - 100) } & $1.021 * *$ & $1.024 * * *$ & 1.003 & 1.006 \\
\hline & $(0.011)$ & $(0.009)$ & $(0.007)$ & $(0.006)$ \\
\hline \multirow{2}{*}{$\begin{array}{l}\text { Average 2006-2010 y-to-y change in IFGF (0 - } \\
100)\end{array}$} & 0.987 & 0.991 & 0.985 & 0.987 \\
\hline & $(0.024)$ & $(0.020)$ & $(0.016)$ & $(0.017)$ \\
\hline \multicolumn{5}{|l|}{ Influence on HD: Demand for $H D$} \\
\hline \multirow[t]{2}{*}{$2000 \%$ of $6-17 \mathrm{y}-\mathrm{o}$ population } & 1.042 & 1.043 & 1.013 & 1.015 \\
\hline & $(0.068)$ & $(0.095)$ & $(0.042)$ & $(0.055)$ \\
\hline \multirow[t]{2}{*}{$2000-2010$ change in $\%$ of $6-17 \mathrm{y}$-o population } & 1.045 & 1.060 & 0.999 & 1.002 \\
\hline & $(0.078)$ & $(0.121)$ & $(0.045)$ & $(0.057)$ \\
\hline \multirow[t]{2}{*}{$2000 \%$ of population living in urban areas } & $0.985^{* *}$ & $0.985^{*}$ & $0.991 * *$ & $0.991 *$ \\
\hline & $(0.006)$ & $(0.009)$ & $(0.004)$ & $(0.005)$ \\
\hline \multirow{2}{*}{$\begin{array}{l}2000-2010 \text { change in } \% \text { of population living in } \\
\text { urban areas }\end{array}$} & 1.004 & 0.998 & 1.001 & 0.999 \\
\hline & $(0.016)$ & $(0.012)$ & $(0.010)$ & $(0.007)$ \\
\hline \multirow[t]{2}{*}{2000 Population: From 20,001 to 50,000 } & 1.432 & 1.282 & 1.216 & 1.151 \\
\hline & $(0.375)$ & $(0.271)$ & $(0.203)$ & $(0.175)$ \\
\hline \multirow[t]{2}{*}{2000 Population: From 50,001 to 100,000} & $3.631 * * *$ & $2.828 * *$ & $1.669 *$ & $1.556^{*}$ \\
\hline & $(1.612)$ & $(1.474)$ & $(0.451)$ & $(0.389)$ \\
\hline \multirow[t]{2}{*}{2000 Population: $100,001+$} & $17.052 * * *$ & $12.809 * * *$ & $3.864 * * *$ & $3.470 * * *$ \\
\hline & $(12.644)$ & $(9.543)$ & $(1.393)$ & $(0.911)$ \\
\hline \multirow[t]{2}{*}{$2000-2010 \%$ change in total population } & 0.998 & 0.995 & 1.001 & 0.999 \\
\hline & $(0.007)$ & $(0.005)$ & $(0.004)$ & $(0.004)$ \\
\hline \multicolumn{5}{|l|}{ Influence on HD: Initial HD level } \\
\hline \multirow[t]{2}{*}{2000 Longevity MHDI quartile: Lowest } & $5.208 * * *$ & $5.088 * * *$ & $2.608 * * *$ & $2.566 * * *$ \\
\hline & $(1.636)$ & $(1.638)$ & $(0.559)$ & $(0.710)$ \\
\hline \multirow[t]{2}{*}{2000 Schooling MHDI quartile: Lowest } & $4.233 * * *$ & $3.847 * * *$ & $1.772 * * *$ & $1.732 * * *$ \\
\hline & $(1.359)$ & $(1.098)$ & $(0.359)$ & $(0.367)$ \\
\hline \multirow[t]{2}{*}{ Constant } & 0.243 & 0.899 & 0.059 & 0.178 \\
\hline & $(0.713)$ & $(2.480)$ & $(0.119)$ & $(0.389)$ \\
\hline Observations & 1,163 & 1,164 & 2,345 & 2,345 \\
\hline Dummies for states & Yes & Yes & & \\
\hline Random intercepts for states & & Yes & & Yes \\
\hline
\end{tabular}

Notes: Calculated with robust standard errors. Pseudo- $\mathrm{R}^{2}$ for specifications (4a) and (5a) are 0.465 and 0.202 , respectively. $(0-100)=$ In a 0 to 100 scale. $* * * \mathrm{p}<0.01, * * \mathrm{p}<0.05, * \mathrm{p}<0.10$.

Source: The author, based on raw data from Atlas do Desenvolvimento Humano no Brasil; Finbra - Finanças do Brasil; Sistema Firjan; Matriz de Informação Social. 